\title{
Importance of the origin of mesenchymal (stem) stromal cells in cancer biology: "alliance" or "war" in intercellular signals
}

\author{
Noemi Eiro ${ }^{1 *}$, Maria Fraile ${ }^{1}$, Silvia Fernández-Francos ${ }^{1}$, Rosario Sánchez ${ }^{2}$, Luis A. Costa ${ }^{1}$ and \\ Francisco J. Vizoso ${ }^{1,2^{*}}$ (1)
}

\begin{abstract}
Mesenchymal stem cells (MSCs) play a central role in the intercellular signaling within the tumor microenvironment (TME), exchanging signals with cancer cells and tumor stromal cells, such as cancer-associated fibroblasts and inflammatory mononuclear cells. Research attributes both pro-tumor and anti-tumor actions to MSCs; however, evidence indicates that MSCs specific effect on the tumor depends on the source of the MSCs and the type of tumor. There are consistent data proving that MSCs from reproductive tissues, such as the uterus, umbilical cord or placenta, have potent anti-tumor effects and tropism towards tumor tissues. More interestingly, products derived from MSCs, such as secretome or extracellular vesicles, seem to reproduce the effects of their parental cells, showing a potential advantage for clinical treatments by avoiding the drawbacks associated with cell therapy. Given these perspectives, it appears necessary new research to optimize the production, safety and antitumor potency of the products derived from the MSCs suitable for oncological therapies.
\end{abstract}

Keywords: Tumor microenvironment, Uterine mesenchymal stem cell, Cancer associated fibroblasts, Macrophage associated cancer

\section{Introduction}

The worldwide number of cancer patients is expected to increase from 14 million in 2012 to more than 19 million in 2025 (http://www.wcrf.org/cancer_statistics/world_ cancer_statistics.php). Despite all the improvements made in its prevention, diagnosis and treatment, cancer still supposes and will be an important cause of morbidity and mortality. In addition to this, we have to consider the adverse effects of treatments such as chemotherapy, radiotherapy, hormonal therapy and immunotherapy. For all these reasons, it is time to try new therapeutic alternatives through the new emerging paradigms of science and

\footnotetext{
${ }^{*}$ Correspondence: noemi.eiro@hospitaldejove.com;

investigacion@hospitaldejove.com

${ }^{1}$ Unit Research, Fundación Hospital de Jove, Avda. Eduardo Castro 161, 33290 Gijón, Asturias, Spain

Full list of author information is available at the end of the article
}

medicine. On the lookout for that, we probably have to start from the basis of cancer. Cancers are the result of a complex interaction between cancer cells and their tumor microenvironment (TME), which comprises extracellular vesicles, bioactive soluble molecules, cellular matrix and, mainly, stromal cells. The interactions between tumor cells and the non-malignant stromal cells display a key role for the TME, and consequently, a crucial gear for the pathophysiology of cancer. Stromal cells are key structural and functional elements in all human carcinomas, comprised of immune cells (macrophages, neutrophils, mast cells, T- and B-lymphocytes), fibroblasts, endothelial cells, pericytes and mesenchymal (stem) stromal cells (MSCs) [1]

MSCs, non-hematopoietic and multipotent cells, were first described by hematologist A. Friedenstein and his collaborators, approximately 50 years ago,

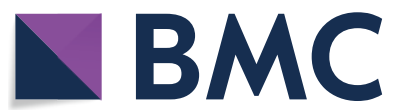

(c) The Author(s) 2021. This article is licensed under a Creative Commons Attribution 4.0 International License, which permits use, sharing, adaptation, distribution and reproduction in any medium or format, as long as you give appropriate credit to the original author(s) and the source, provide a link to the Creative Commons licence, and indicate if changes were made. The images or other third party material in this article are included in the article's Creative Commons licence, unless indicated otherwise in a credit line to the material. If material is not included in the article's Creative Commons licence and your intended use is not permitted by statutory regulation or exceeds the permitted use, you will need to obtain permission directly from the copyright holder. To view a copy of this licence, visit http://creativeco mmons.org/licenses/by/4.0/. The Creative Commons Public Domain Dedication waiver (http://creativecommons.org/publicdomain/ zero/1.0/) applies to the data made available in this article, unless otherwise stated in a credit line to the data. 
as a rare population ( 1 in 10,000 nucleated cells) in the bone marrow. [2]. In 2006, the criteria required for MSCs' definition have been defined as follows: (a) plastic-adherent cells when maintained in standard culture conditions; (b) simultaneous expression of stromal markers (CD29, CD44, CD73, CD90, and CD105), but negative for hematopoietic (CD45 and CD14) or endothelial (CD31 and CD34) markers and HLA-DR surface molecules and (c) capacity to differentiate into adipocytes, osteoblasts and chondroblasts in vitro [3].

Although in small amounts, MSCs are present in all organs and tissues, where they play a role in homeostatic maintenance. In fact, many chronic autoimmune or degenerative diseases such as diabetes, lupus, rheumatoid arthritis or psoriasis, and even syndromes associated with early aging, have been shown to have dysfunction or depletion of MSCs. Multiple in vitro studies have demonstrated that MSCs exert a regulatory effect in basic cellular processes such as inflammation, oxidative stress, angiogenesis, etc. Consequently, in vivo studies have demonstrated their efficacy in many animal models (for review, [4]). Furthermore, MSCs are good candidate for cell therapy considering their immune privileged status that allows them to evade immune rejection. Clinical trials have demonstrated the safety and efficacy (phase III clinical trials) of MSCs-based cell therapy for lupus, graft-versus-host disease, diabetes, myocardial infarction or perianal fistulas in Crohn's disease (for review, [5]).

Despite the use of MSCs-based cell therapy, it is now assumed that the mechanism of action of MSCs is basically paracrine. MSCs do not survive long in the body once administered; but during that time, they secrete a cocktail of factors exhibiting a wide spectrum of biological actions. That MSCs-derived secretome is made up of cytokines, hormones and extracellular vesicles, among others. It is considered that MSCs secretome may represent a therapeutic alternative that will avoid the inconveniences associated with cell therapy such as immune compatibility, tumorigenicity or transmission of infections, among others [6].

Regarding cancer, there are controversial data about the role of MSCs, pointing to either tumor promotion or anti-tumorigenic functions in several types of tumors. This points to the importance of MSCs and cancer heterogeneity, as the effects of MSCs on cancer biology could differ depending on the source of MSCs and the type of tumor. This review addresses the current knowledge on MSCs in tumors development and progression, their biological influence and also explores the potential therapeutic strategies for cancer based on MSCs and MSCs-derived products.

\section{Pro-tumor and anti-tumor effects of MSCs}

The tumors were described by Devorak as a "wound that never heals" [7]. In this microenvironment scenario, cancer cells produce a cocktail of growth factors (EGF, HGF, SCF, IGF-1, VEGF, PDGF or $\beta F G F$ ), cytokines (IL-1 $\beta$, IL-8, TNF- $\alpha$ or TGF- $\alpha$ ) and chemokines (CCL2, CCL5, CCL22 or CXCL12) that induce the recruitment of MSCs to the tumor locations, as it has been shown for different types of cancer such as breast, ovarian, gastric, pancreatic, colorectal, skin cancer or melanoma (for review, [8]). Although the exact mechanism for this recruitment remains still unknown, several studies have shown that exogenous MSCs have the ability to migrate into injured tissues, including tumors, up to almost one day after intravenous injection [9]. Literature shows divergent data regarding the anti-tumoral potential of MSCs depending on their tissue origin and the tumor type (Tables 1 and 2).

\section{Pro-tumor functions}

Among the proposed mechanisms for MSCs contributing to tumor progression are: (i) Promotion of increased function and count of tumor stroma cells, (ii) Promotion of angiogenesis (iii) Suppression of the immune response to tumor, (iv) Enhancement of tumor cell survival, cancer cell aggressiveness and tumor metastasis and (v) Enhance of drug resistance.

\section{Promotion of increased function and count of tumor stroma cells}

MSCs show the ability to differentiate into different cell types of the tumor stroma, which in turn, have the ability to contribute to tumor progression, such as cancer associated fibroblasts (CAF), cancer associated adipocytes (CAA), pericytes or endothelial-like cells.

CAF, which differ from normal fibroblasts by presenting a different gene expression profile and promoting cancer cell aggressiveness [38], are one of the most abundant cell types in the cancer stroma of human tumors. MSCs have been shown to have a great ability to differentiate into CAF in the TME compared to non-neoplastic tissues [39]. This may be due to the factors released by cancer cells, that would induce the activation of the TGF- $\beta$ /Smad signaling pathway [40].

Among the different mechanisms by which CAF promote tumor progression are the following: (i) contractile forces exerted by CAF that can alter the basement membrane, facilitating cancer cell invasion; (ii) production of metalloproteases inducing the degradation of the extracellular matrix (ECM); (iii) angiogenic promotion; (iv) epithelial-mesenchymal transition (EMT) activation; (v) metabolic reprogramming toward a reverse Warburg phenotype; (vi) secretion of key biological factors (such 
Table 1 Pro-tumor effects of MSCs on the biology of different types of tumors

\begin{tabular}{|c|c|c|c|c|c|}
\hline MSC source & Product administrated & Tumor type & Type of study & Outcome effect & References \\
\hline \multirow[t]{6}{*}{ Bone marrow } & \multirow[t]{5}{*}{ Cells } & MDA-MB-231 breast cancer cells & $\begin{array}{l}\text { In vitro } \\
\text { In vivo }\end{array}$ & $\begin{array}{l}\text { Increase metastasis/activation of the } \\
\text { hypoxia-inducible factors }\end{array}$ & [10] \\
\hline & & $\begin{array}{l}\text { MDA-MB-231 and MCF7/Ras breast } \\
\text { cancer cells }\end{array}$ & $\begin{array}{l}\text { In vitro } \\
\text { In vivo }\end{array}$ & $\begin{array}{l}\text { Promotes breast cancer invasion, } \\
\text { epithelial-to-mesenchymal transi- } \\
\text { tion and metastasis. Promote de } \\
\text { novo production of lysyl oxidase } \\
\text { (LOX) }\end{array}$ & [11] \\
\hline & & HT-29 colorectal cancer cells & $\begin{array}{l}\text { In vitro } \\
\text { In vivo }\end{array}$ & $\begin{array}{l}\text { Promoted tumor sphere formation } \\
\text { and tumor initiation/activation of } \\
\text { Janus kinase 2-signal transducer } \\
\text { and increased of IL-6 secreted by } \\
\text { MSCs signaled through STAT3 }\end{array}$ & {$[12]$} \\
\hline & & 4T1 mouse mammary tumor cell line & In vitro & $\begin{array}{l}\text { Increased tumor growth. Protect } \\
\text { breast cancer cells from immune } \\
\text { clearance, MSC suppressed the } \\
\text { proliferation of PBMC. Inhibition } \\
\text { of PBMC migration toward breast } \\
\text { cancer cells }\end{array}$ & [13] \\
\hline & & BxPC3 pancreatic cancer cells & $\begin{array}{l}\text { In vitro } \\
\text { In vivo }\end{array}$ & $\begin{array}{l}\text { Increase tumor invasion. Increased } \\
\text { secretion of MMP-3, amphiregulin } \\
\text { and its receptor EGFR }\end{array}$ & [14] \\
\hline & Extracellular vesicles & $\begin{array}{l}\text { MG63 osteosarcoma cancer cells and } \\
\text { SGC7901gastric cancer cells }\end{array}$ & In vitro & $\begin{array}{l}\text { Foster cell growth. Activation of } \\
\text { Hedgehog signaling pathway }\end{array}$ & [15] \\
\hline \multirow[t]{2}{*}{ Adipose tissue } & \multirow[t]{2}{*}{ Cells } & MCF-7 breast cancer cells & $\begin{array}{l}\text { In vitro } \\
\text { In vivo }\end{array}$ & $\begin{array}{l}\text { Stimulate migration and invasion/ } \\
\text { secretion of IL-6 }\end{array}$ & [16] \\
\hline & & $\begin{array}{l}\text { MCF-7 and MDA-MB-231 breast } \\
\text { cancer cells }\end{array}$ & $\begin{array}{l}\text { In vitro } \\
\text { In vivo }\end{array}$ & $\begin{array}{l}\text { Promote tumorigenesis and angio- } \\
\text { genesis/bidirectional signaling; } \\
\text { ADSCs differentiated into cancer- } \\
\text { associated myofibroblasts }\end{array}$ & [17] \\
\hline
\end{tabular}

as cytokines: IL-1 $\beta$, IL-6, IL-8; growth factors: SDF-1, FGF, HGF; and NFkB) to induce immune cell recruitment that may contribute to tumor progression, (vii) induction of resistance to cancer therapy (for review, [1, 41]).

Similarly, CAA also differ from the normal adipocytes in their high metabolic activity and in their ability to generate a variety of growth factors, hormones, cytokines and adipokines, which induce tumor growth, metastasis and therapy resistance (for review, [41]). In addition, adiponectin, which plays an anti-tumorigenic role by inducing apoptosis, is decreased in CAA [42].

\section{Promotion of angiogenesis}

Due to the high demand of oxygen and nutrients by cancer cells, the development of new blood vessels from existing vasculature is necessary to sustain either the early steps of tumor development as its progression [43]. In vitro studies reported that different MSCs populations induce the proliferation and migration of endothelial cells, promoting tube formation and preventing endothelial cell apoptosis [44].

Experimental results indicate that tumor growth promotion in vivo by MSCs may be attributable, in part, to enhanced angiogenesis [45]. MSCs can increase angiogenesis through the induction of ERK1/2 and p38 MAPK pathways, which enhance the expression of VEFG and CXCR4 in tumor cells [46]. MSCs also contribute to tumor angiogenesis through their potential to differentiate into endothelial-like cells and/or pericytes [47, 48]. In addition, it has been shown that MSCs secrete pro-angiogenic soluble factors such as VEGF, PDGF, angiopoetin, LIF, M-CSF, MIP-2, IL-6, IL-8, TGF- $\beta$, IFN- $\gamma$, $\beta$-FGF and TNF $\alpha[16,49-52]$. Otherwise, angiogenic inhibitors have been also identified in the MSCs secretome [53]. Nevertheless, the secretion of these pro- and anti-angiogenic factors by MSCs, can be modified by regulating several factors such as hypoxic conditions, which is a common condition in tumors [54].

\section{Suppression of the immune response to tumor}

MSCs are key regulators of innate and adaptive immune responses and possess strong immunosuppressive properties, which would support the potential evasion of tumor cells from anti-cancer immunity [55]. MSCs within the TME could induce immunosuppression mainly by the secretion of soluble factors and mediators such as 


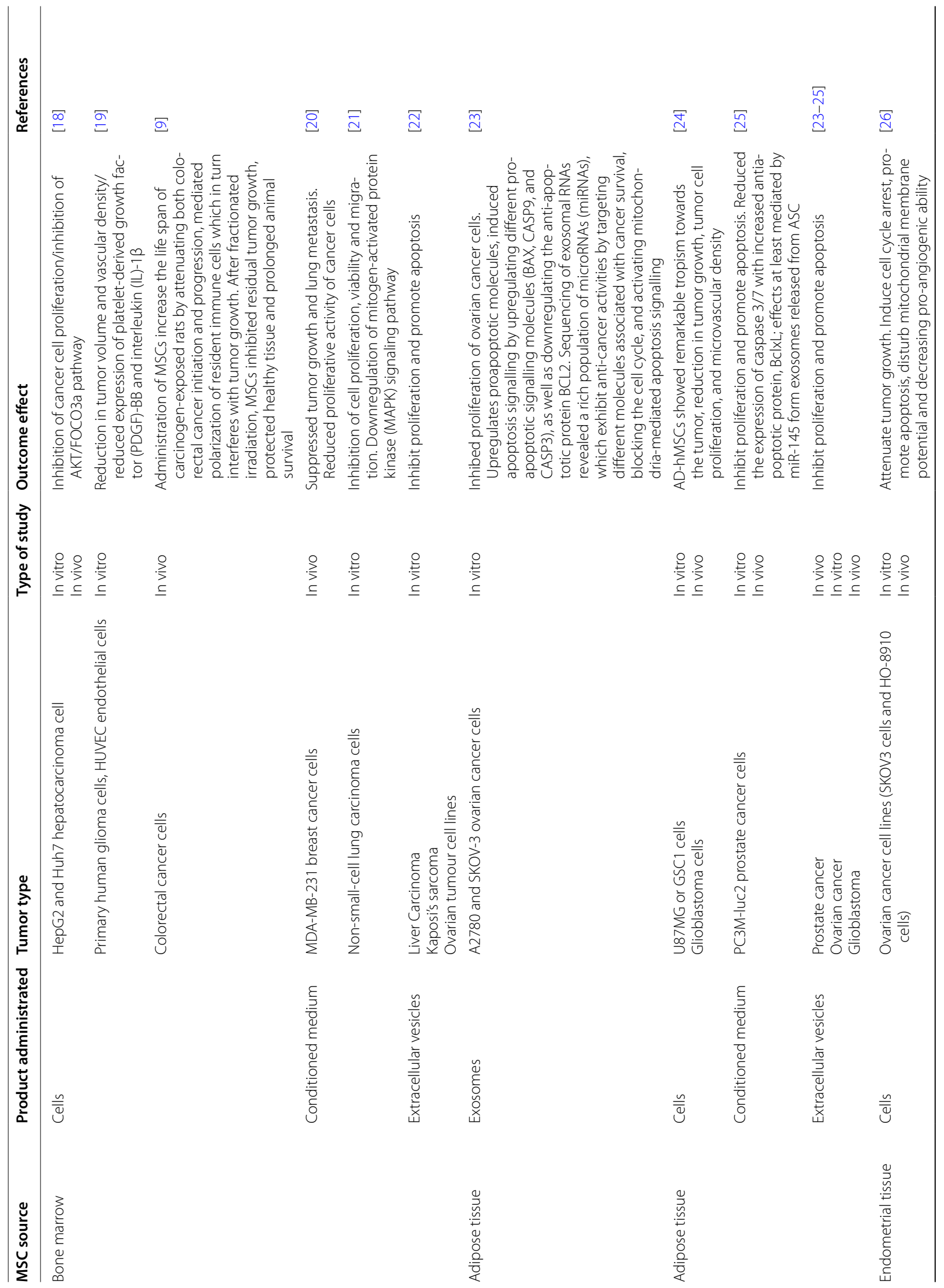




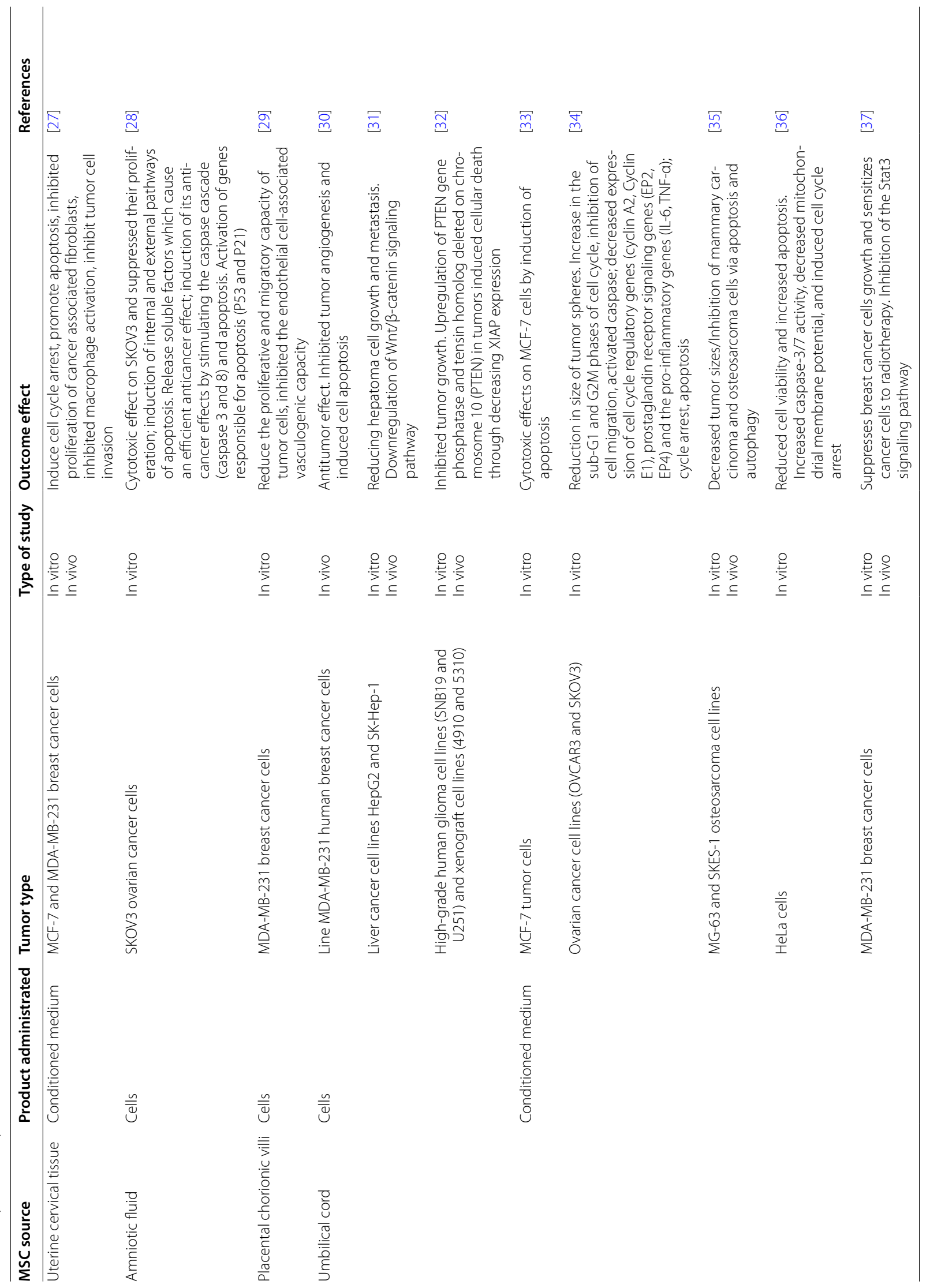


cytokines (TGF- $\beta$, HGF, IFN- $\gamma$, TNF- $\alpha$, IL- $1 \alpha$, IL- $1 \beta$, IL-4, IL-6 and IL-10), prostaglandin E2 (PGE2), HLA-G, nitric acid, indoleamine 2,3-dioxygenase (IDO) and prostaglandin E2 indoleamine, as well as by their interactions with various immune cell types. [55-59]. Table 3 shows pro-tumor effects of MSCs on several immune cells, such as neutrophils, dendritic cells, natural killer cells, T cells, B cells, macrophages and myeloid-derived suppressor cells.

\section{Enhancement of tumor cell survival, cancer cell aggressiveness and tumor metastasis}

MSCs have been found to release many soluble factors that promote tumor survival and its proliferation, including VEGF, FGF-2, PDGF, HGF, BDNF, SDF-1 $\alpha$, IGF-1, IGF-2, TGF- $\beta$, and IGFBP-2 [78-80].

Epithelial-mesenchymal transition (EMT) is a process in which epithelial cells undergo multiple changes to gain mesenchymal properties. EMT is a relevant phenotypic change allowing cancer cells to detach from the primary tumor, being the initial step in metastatic spread. This process implicates the activation of several transcription factors (Snail, Slug, Twist, and FOXC2) [81] and a decreased E-cadherin expression [82]. Paracrine signals of MSCs, via secretion of growth factor or cytokines (EGF, HGF, PDGF or TGF- $\beta$ ) may induce these EMTspecific transcription factors [83, 84]. In addition, it has been shown that MSCs within the tumor stroma of breast cancer enhance EMT by producing CCL5 (also called RANTES). CCL5 increases the secretion of MMP-9, which degrade basal membrane and extracellular matrix, promoting cancer cell motility and metastasis [85].
Nowadays, it is assumed that cancer stem-like cells (CSC) represent a cell subpopulation of tumors responsible for cancer initiation, and also in charge of the final steps of colonizing premetastatic niches and chemotherapy resistance [86]. Experimental evidence indicates that MSCs increase stemness of cancer cells by secreting factors capable of activating pathways such as JAK2 / STAT3 in lung cancer cells [87];secreting CXCL7 [88] and increasing P2X-mediated signaling [89] in breast cancer cells; potentiating WNT and TGF- $\beta$ signaling pathways in gastric cancer [90]; activating the Hedgehog/BMP4 signaling loop in ovarian cancer [91]; and via IL-8/mitogen-activated protein kinase (MAPK) in colorectal cancer [92]. Interestingly enough, it has been also reported that gastric mucosal cells, after being infected with Helicobacter pylori, recruit MSCs to the site of the infection and then they differentiate into gastric cells expressing epithelial markers (such as KRT1-19 and TFF2), which together with chronic inflammation, could promote a CSC phenotype of gastric cancer [93].

MSCs are involved in other mechanisms critically contributing to the metastatic process, either at the primary tumor or at pre-metastatic sites. MSCs secrete TGF$\beta$, which increases cancer cells' invasive and migratory potential [94]. In addition, they secrete chemoattractants such as CCL5, CXCL1, CXCL5, CXCL7 and CXCL8 and CXCL12, which induce migration of tumor cells to metastatic lesions [85, 95]. Among these factors regulating the trafficking of tumor cells, CXCL12 seems to be especially relevant, as metastatic cells express its major receptor, CXCR4 $[96,97]$. MSCs have also been proved to support

Table 3 Immunosuppressive effects of MSCs on several immune cell types which contribute to tumor progression

\begin{tabular}{|c|c|c|}
\hline Immune cells & MSCs effects & References \\
\hline Neutrophils & $\begin{array}{l}\text { Induction of CD1 1 b/Ly6G-positive neutrophils to massive T-cell inhibition in vitro, and enhancement of breast carci- } \\
\text { noma tumor growth in vivo } \\
\text { IL-6 from cancer-derived MSC promotes neutrophil activation via STAT3-ERK1/2 signaling and induces their polariza- } \\
\text { tion towards a tumor-supportive phenotype in gastric cancer }\end{array}$ & {$[60,61]$} \\
\hline Dendritic cells & $\begin{array}{l}\text { Suppression of dendritic cell differentiation by downregulating IFN- } y \text { and TNF-a expression } \\
\text { Regulation of maturation of dendritic cells via PGE2 signalling } \\
\text { Promotion of immunosuppressive effects on dendritic cells and tumor growth in murine melanoma tumor models }\end{array}$ & [62-64] \\
\hline Natural killer & Block its activity, suppressed its proliferation and cytokine secretion and reduce its ability to produce IFN- $\gamma$ & {$[65,66]$} \\
\hline T-cells & $\begin{array}{l}\text { Repress T-cells proliferation and increase apoptosis by secreting soluble TGF- } \beta \\
\text { Secrete IDO, which inhibits T-cells through tryptophan depletion }\end{array}$ & {$[13,67-70]$} \\
\hline B-cells & $\begin{array}{l}\text { Repress B-cell proliferation by secreting soluble factors } \\
\text { Reduce antibody production and inhibit their differentiation to plasma cells } \\
\text { Attenuate B-cell proliferation and antibody production by INF-y stimulated-MSCs overexpression galectin-9 }\end{array}$ & [70-73] \\
\hline Macrophages & $\begin{array}{l}\text { Induce macrophages to produce the anti-inflammatory factor IL-10 } \\
\text { Decrease the phagocytic abilities of macrophages, thereby promoting a pro-tumorigenic macrophage phenotype } \\
\text { by secreting soluble factors }\end{array}$ & [74-76] \\
\hline $\begin{array}{l}\text { Myeloid-derived } \\
\text { suppressor cells }\end{array}$ & Protect against autoimmunity by recruitment of myeloid-derived suppressor cells via CCL2 signalling & [77] \\
\hline
\end{tabular}


metastatic niches due to their strong adhesive activities, mediated by adhesion molecules and integrins [98].

\section{Promotion of drug resistance}

Tumor resistance to chemotherapy remains one of the major obstacles of modern clinical oncology. MSCs may contribute to drug resistance as there are evidence illustrating this effect, although the exact mechanisms are not entirely known. As discussed above, MSCs might promote drug resistance through activation of EMT, CAF and especially, CSC. CSC represent a unique, rare population of cells within tumors that resist to many cytotoxic agents using several mechanisms, such as their low proliferative rate, their high DNA repair capabilities and their expression of membrane transporters to control a cytotoxic drug influx [99].

Curiously, MSCs may be recruited in large number to tumors in response to chemotherapy helping cancer cells develop the resistance to the therapy [100]. In addition, there are evidence indicating that pre-exposure of MSCs to chemotherapeutic agents alters phosphorylation levels of several tyrosine kinases (WNK-1, c-Jun, STAT3 and p53), favoring MSCs survival and stimulating their production of cytokines, which would promote chemoresistance of tumor cells [101].

Paracrine secretion of IL- 6 by MSCs may induce chemoresistance to cisplatin in thymus residing endothelial cells in mice [102], or to paclitaxel in head and neck carcinoma [103]. It also been pointed that activation of CXCL12-CXCR4 axis in MSCs reduces imatinib-induced cell death in chronic myeloid leukemia [104], or protect cancer cells from hyperthermia-induced cell death induced by intraperitoneal chemotherapy in ovarian cancer cells [105]. In pancreatic adenocarcinoma, MSCs increased chemoresistance to gemcitabine by activating the CXCL10-CXCR3 axis [100]. Other protectivedrug activities of MSCs were described, for example, increasing RNA and protein synthesis against the cytotoxic effects of forodesine in chronic lymphoid leukemia [106], or by secreting polyunsaturated fatty acids (12-oxo-5,8,10-heptadecatrienoic acid [KHT], and hexadeca-4,7,10,13-tetraenoicacid $[16: 4(n-3)])$ which may have an indirect protective effect against cisplatin [107].

\section{Anti-tumor functions}

In addition to the pro-tumorigenic effects described above, other studies have shown that MSCs act in an anti-tumorigenic manner suppressing disease progression. Studies, both in vivo and in vitro, have explained that MSCs can inhibit tumor growth and metastasis through several mechanisms such as: (i) Regulation of cellular signaling pathways and induction of apoptosis, (ii) Inhibition of angiogenesis (iii) Modulation of immune response.

\section{Regulation of cellular signaling pathways and induction of apoptosis}

MSCs can attenuate cancer cell proliferation by paracrine inhibition of cell signaling pathways in several types of tumors, such as breast, ovary, stomach, colon, liver and skin. These mechanisms include the inhibition or suppression of phosphoinositide 3-kinase PI3K/AKT, and WNT/ $\beta$-catenin signaling pathways [108-110]. MSCs from several sources have been also reported to induce tumor cell apoptosis. MSCs from gingival tissue induce cell death of oral cancer cells [111]. Also, it has been reported the induction of apoptosis of breast cancer cells by adipose derived (AD)-MSCs through IFN- $\gamma$ induction [112], and MSCs from the human uterine cervix (hUCESC) are capable of inducing death of cancer and stromal cells through caspase 3 and annexin V activation [27].

\section{Inhibition of angiogenesis}

Although, as described above, there is evidence indicating proangiogenic effects of MSCs, there are also data indicating that, under certain circumstances, some types of MSCs can exert an anti-angiogenic effect. Thus, umbilical cord (UC)-MSCs have been described to inhibit angiogenesis as in vitro as in vivo in gliomas, which is accompanied by a downregulation of pro-angiogenic factors (PDFG-BB, IGF-1, FGF-2, and IL-1 $\beta$ ) [19]. It has also been described that human placental chorionic villiderived MSCs inhibited the endothelial cell-associated vasculogenic capacity of the breast cancer cell line MDAMB-231 on HUVEC cells [29]. These data suggest that the involvement of MSCs in angiogenesis is highly regulated and further studies will be required to fully understand it.

\section{Modulation of immune response}

It is widely accepted that MSCs tend to be more protumorigenic than anti-tumorigenic because of their immunosuppressive and regenerative activities [113115]. Nevertheless, there is other evidence indicating the possibility of an MSCs-induced anti-tumor modulation of the immune system in the TME. It has been reported that the immortalized mesenchymal progenitor cell line $\mathrm{MPC} 1 \mathrm{cE}$ increased monocyte and granulocyte infiltration in tumors, inhibiting cancer growth in a rat colon cancer model [116]. In addition, there are data indicating that bone marrow (BM)-MSCs can induce changes in the immune cell phenotypes towards an anti-tumor behavior, such as altering the ratio of Treg and myeloid-derived suppressor cells to CD8+ $\mathrm{T}$ cells [117], increasing 
neutrophil function through Toll-like receptor 3 (TLR3) activation [118, 119], as well as hUCESC inhibiting and reverting macrophage differentiation [27]. Interestingly, in a recent study in a colorectal cancer model in immunocompetent rats, BM-MSCs were able to modulate the inflammatory response during the early phase of chemically-induced carcinogenesis. Locally, mRNA levels of several proinflammatory genes, including IL-1 $\beta$, IL-6, TNF- $\alpha$, and MIP-2, were significantly downregulated, whereas mRNA levels of the anti-inflammatory genes IL-10 and TGF- $\beta$ were upregulated. Even more, a polarization of resident macrophages into the M1 subtype was observed [9].

It is also important to note that CAF could mediate inflammation and by recruiting macrophages stimulate angiogenesis, which may promote tumor growth [120]. In this regard, it has been showed that hUCESC reduce cell proliferation, increase apoptosis and decrease invasion capacity of CAF [27].

\section{MSCs tumor or anti-tumor effects depending on MSCs origin and tumor type}

The effects of MSCs on tumors are still controversial $[115,121,122]$, although it is widely accepted that MSCs tend to be more pro-tumorigenic than anti- tumogenic, by being immunosuppressive. However, based on the accumulated information during the last decade, it is time to accept a new scenario in which the pro-tumor or anti-tumor effect of MSCs depends on the source of MSCs and the type of tumor. In fact, the most heterogeneous effects of MSCs, according to their origins, are those occurring on tumors [123, 124]. As can be observed in Tables 1 and 2, we can conclude that BM-MSCs and their secretome derived products have pro-tumor effects on pancreatic and gastric cancer cells, whereas they have anti-tumor effects against glioma cells and non-small-cell lung carcinomas, and there are conflicting results about the effect of these cells on breast and colorectal carcinomas. In regard to AD-MSCs, anti-tumor effects were found in ovarian, prostate and glioblastoma cancer cells, but discordant results are indicated for breast cancer cells. Also, it is important to note the different behavior and effects in tumors depending on the use of cells or their secretome-derived products. Thus, it has been shown that secretome-derived products of BM-MSCs, such as conditioned medium or exosomes, are able to reduce proliferation and migration and increase the apoptosis of certain types of cancer cells, such as nonsmall-cell lung carcinoma, liver carcinoma, Kaposi's sarcoma, and ovarian tumor cell lines. The same effect was reported for extracellular vesicles (EVs) from AD-MSCs, that inhibit prostate cancer, ovarian cancer cells, or glioblastoma (Table 2).
On the other hand, relevant and consistent results are found regarding MSCs from uterine origin. In all studies, including MSCs from endometrial, uterine cervical, as well as other reproductive tissues (amniotic fluid, placental chorionic villi and umbilical cord), potent anti-tumors effects have been found against breast, ovarian, liver, glioma or osteosarcoma cancer cells. These data may indicate that MSCs derived from reproductive tissues could have a genuine anti-tumor effect. For example, it has been indicated that UC-MSCs have a high tendency to move toward tumor cells and inhibit the growth of solid tumor cells such as breast [33, 34] or HeLa cells [35, 36]. The unique feature of these cells leads to the hypothesis suggesting that UC-MSCs may act as a natural defense against the migration of cancer cells from the mother to the fetus, justifying why tumors in fetus are very rare [125]. In any case, these functional particularities of MSCs according to their anatomical location, allow us to consider the existence of MSCs with special capacities pursuant to their biological environment. In this context, it is reasonable to consider the existence of MSCs accustomed to regulate homeostasis in tissues highly exposed to external aggressions. One location that appears to be candidate for hosting this kind of special MSCs is the uterine cervix.

The human uterine cervix is permanently in contact with a mildly aggressive environment (bacteria and acid $\mathrm{pH}$ ) that may become overly pathogenic (infection by fungi or some strains of the papillomavirus family). At this location, a process known as "squamous metaplasia", by which the glandular cells of the endocervical epithelial lining convert into squamous epithelial cells of the ectocervix, take place. This process is a biologically very risky process, because it implies a regression of the original transforming cell into a highly undifferentiated state, from which it can redifferentiate into the new kind of cell required. For one thing, a highly undifferentiated cell is prone to uncontrolled hyperproliferation, which is the first step in the oncogenic transformation process. For another thing, it is more vulnerable to the infection by viruses, in this case most notably by the oncogenic variants of the papillomavirus family, due to a higher DNA replication activity. Similarly, on breast cancer, hUCESCs do indeed allow a certain degree of hyperproliferation, so that they do not act on the non-invasive, low-proliferating MCF-7 cell line. Notwithstanding, once a critical threshold is reached, they exert a very potent and effective anti-tumor activity against highly proliferating and metastasis-producing cancer cells, such as the MDAMB-231 breast cancer cells tested. All these effects were reproduced in an almost identical fashion on cell lines produced from samples obtained in the clinic from real patients [27]. Therefore, our hypothesis is that hUCESC, 
a very special kind of MSCs embedded in the uterine cervical stroma, have a unique ability to hold all these extreme biological risks under control, by the regulation of proliferation and oncogenic transformation [27], inducing apoptosis if ultimately necessary, [27] and also exerting anti-inflammatory [126], antibacterial [127] and antifungal effects [128] through, among other mechanisms still under study, the secretion into its culture medium of a highly complex cytokine cocktail mediating all of the just mentioned effects, as we shall see hereunder.

\section{Role of the MSCs in the "alliance" and "war" of the intercellular signals from tumor microenvironment}

We can consider tumor growth as the result of the "alliance" or "war" of intercellular signals between the different types of cells in the tumor scenario. Schematically, cancer cells secrete cytokines and chemokines, such as TGF- $\beta$ and CCL2, involved in the recruitment and activation of CAF [129] and mononuclear inflammatory cells, as well as the tumorigenic transformation of macrophages [130]. Furthermore, after recruitment of stromal cells, a complex and dynamic interaction takes place $[1,131]$. In this context, MSCs seems to play a pivotal role, by interacting with cancer cells and stromal cells (Fig. 1). The multi-directional signals between these cells are mediated by soluble factors, integrins, and/or EVs (for review [1]) (apoptotic bodies, microvesicles and exosomes), resulting in a particular nano-communication among the different cell types of the tumor [132]. Exosomes, the smallest subset of EVs (30-150 nm in diameters), are enclosed by a protein-phospholipid bilayer membrane, and its lumen recapitulates, partially, the content of the parent cell (DNA, messenger RNA (mRNA), microRNA (miRNA), nucleic acids, growth factors, cytokines and chemokines) [133, 134].

Tumor cells and MSCs are important producers of exosomes. Tumor-derived exosomes (TDEx) are ubiquitously present in the tumor environment (TME) and in body fluids of patients with cancer [135]. TDEx, whose content depends on the type of tumor cell [136], transmit messages from the parent tumor cell to normal or malignant cells in the TME, including messages to MSCs [137]. These messages to stromal cells and MSCs include the overexpression of genes involved in cell migration, matrix remodeling, angiogenesis and tumor growth [138-140].

Under normal physiological conditions, MSCs also produce high dose of exosomes (MSCs-Ex) [141]. MSCsEx carry a complex cargo of molecules including more than 850 unique gene products and more than 150 different miRNA [142, 143]. Thus, MSC-Ex have the potential to elicit different cellular responses in a broad variety of cells [144], which seem to be responsible for the modulation of many physiological functions $[145,146]$. MSCs

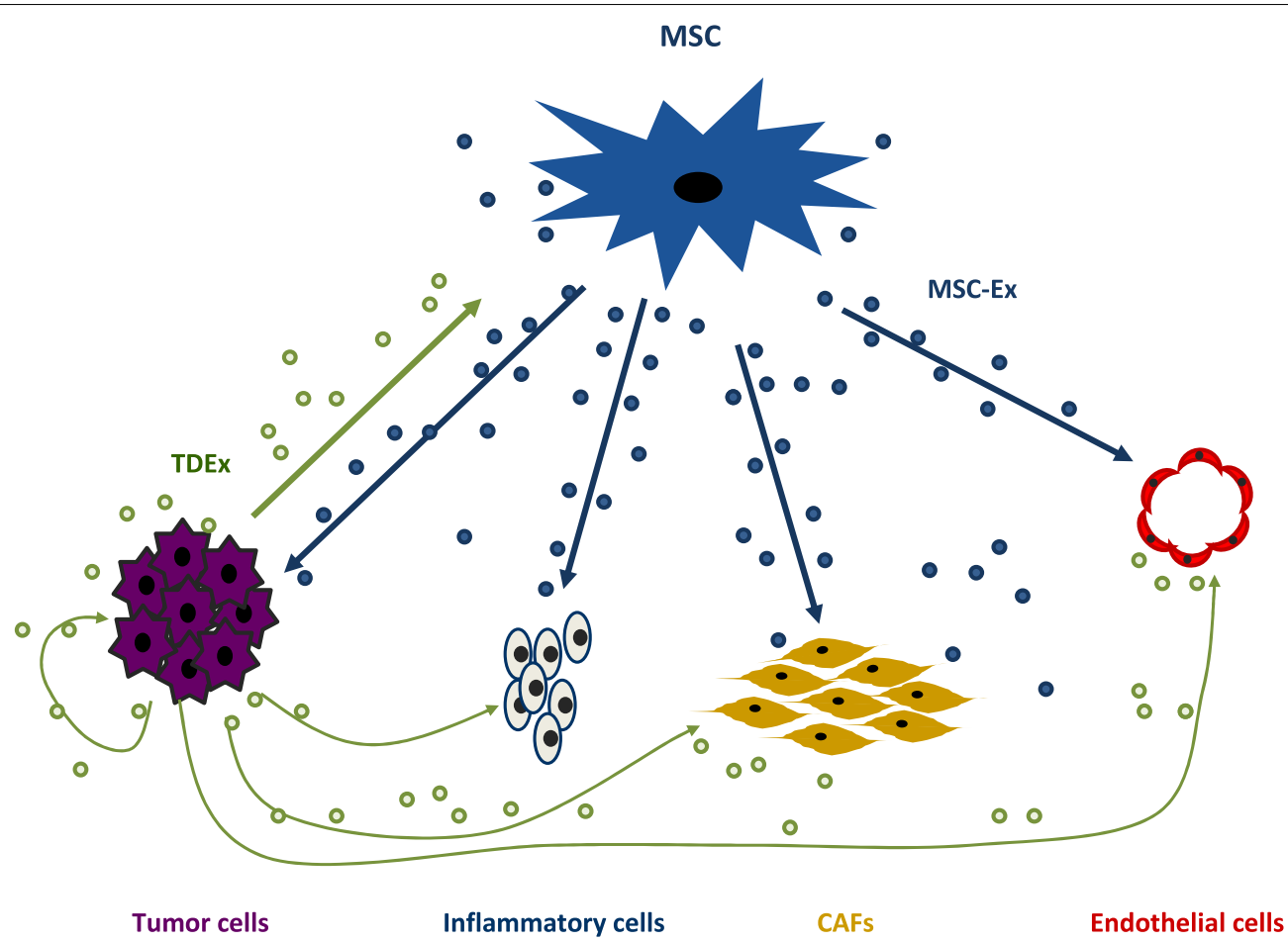

Fig. 1 Scheme of relationships established by the MSCs with different cell-types during tumor progression 
are recognized as recipients for signals from the tumor, but through MSCs-Ex, MSCs have the capacity to interact with multiple cell types in the TME inducing phenotypic and functional changes which may exert profound effects on tumor growth [147]. In a similar way to MSCs, it has been reported that some types of MSCs-Ex can induce and support tumor growth, invasion and metastasis[144, 147, 148], while other MSCs-Ex have anti-tumor actions, depending on their provenance and the type of tumor. For example, it has been found that exosomes derived from MSCs can have an antiproliferative effect and even induce a state of latency in some tumors such as mammary or ovarian tumors [149, 150]. Exosomes obtained from BM-MSCs were also found to inhibit proliferation and promote apoptosis in liver carcinoma, Kaposi's sarcoma, and ovarian tumor cell lines [151] and exosomes derived from AD-MSCs inhibit prostate cancer [25], ovarian cancer cells [23], or glioblastoma cells [24]. In addition, it has been reported that MSCs-Ex from human UC-MSCs attenuate the growth of bladder carcinoma cells, possibly by down-regulating phosphorylation of Akt protein kinase and up-regulating cleaved caspase-3 [152].

Similarly, intratumoral injection of miR-146b-expressing MSCs-Ex resulted in a considerable reduction in glioma xenograft development in a brain tumor rat model by decreasing the growth, migration and invasion of cells [153].

Presently, it is known that one of the antitumor actions of exosomes is largely due to miRNA contained inside. miRNAs are small non-coding RNAs that suppress the translation and stability of mRNA, controlling in this manner several cellular processes, such as cell cycle regulation, cell differentiation and apoptosis. Dysregulation of miRNA has been revealed to play an essential role in the development of tumor progression [154]. In the context of the heterogeneity shown by the MSCs, different populations of exosomes containing miRNA with anti-tumor effects have been described, for example: miRNA-9-3p from exosomes secreted by BM-MSCs suppresses the development of urinary bladder cancer [155], miRNA-143 derived from that same type of MSCsinhibits cell migration and invasion of prostate cancer [156], miRNA-124 derived from UC-MSCs increases chemosensitivity to temozolomide and decrease migration from glioblastoma cells [157], and miRNA-122 derived from MSCs of adipose tissue induces hepatocarcinoma cancer cells to be more sensitive to the chemotherapeutic agent sorafenib [158]. Furthermore, miRNA-379, derived from BM-MSCs, has also recently been shown to induce a decrease in tumor activity and size in breast cancer [159].

The outcome of tumor progression is highly dependent on the outcome of those signal balances, and cancer cells have been demonstrated to internalize higher percentage of exosomes than normal cells $[160,161]$. Then, these EV produced by MSCs can be responsible for many of their anti-tumor effect. Therefore, the use of MSCs with anti-tumor capacity may signify a great opportunity for a therapeutic strategy.

\section{MSCs as therapeutic strategies in tumors \\ MSCs as cell therapy}

As described above, certain MSCs, according to their origin, and especially those from reproductive source, seem to have an anti-tumor effect for specific carcinomas. This, together with the tropism that MSCs show for tumors makes them potential candidates to be applied in future clinical trials. However, it is important to mention that regarding their affinity for tumors, MSCs are being developed as selective vehicles for drug delivery, especially in aggressive neoplasms. For example, MSCs have been used to deliver oncolytic viral loads into tumors, therefore selectively inducing cancer cell killing, preclinically, and most recently, also clinically $[162,163]$. In this same context, MSCs have been also genetically manipulated to express immunodulatory cytokines or specific enzymes, which can promote cancer cell killing effects. It has been presented that MSCs overexpressing IL-12 enhance anti-tumor T cell responses and decrease tumor growth [164]. MSCs genetically modified to produce IFN- $\beta$ induce significant anti-proliferative effects in melanoma cells [165] and in a metastatic prostate cancer preclinical model [166]. In addition, MSCsoverexpressing TNF-related apoptosis-inducing ligand (TRAIL), can effectively eliminate cancer cells in several cancer models including glioma [167], pancreatic [168] and lung cancer [169, 170].

On the other hand, MSCs have been also genetically manipulated to express specific enzymes, such as cytosine deaminase or herpes simplex virus-thymidine kinase (HSV-TK), which convert inactive systemically administrated prodrugs, like fluorouracil and ganciclovir, into active cytotoxic agents [171, 172], offering the advantage to increase tumor-directed chemotherapy activity and to minimize systemic toxicity.

However, currently, there are problems derived from using stem cells themselves, such as immunological incompatibility, tumorigenicity, embolus formation, transmission of infections, and the potential entry of MSCs into senescence [173]. In addition, there are other potential drawbacks related to the expected clinical benefit of MSCs cancer therapy, as their physiological differentiation into mesenchymal lineages that may decrease therapeutic potential [174]. 


\section{MSCs secretome}

Secretomes, aside from avoiding the inconveniences of administering living proliferating cells, show other additional advantages. Unlike cell therapies, secretomes can be better evaluated for their safety, dosage and potency, analogously to conventional therapeutic agents. Secretomes can be stored without the application of potentially toxic cryopreservative agents. The use of products derived from the secretome, such as the conditioned medium or extracellular vesicles (EVs), is cheaper and more practical for clinical use, since the use of the secretome could avoid the time and costs associated with the expansion and maintenance of clonal cell lines. This is due to the fact that the secretome for therapies could be prepared in advance in large quantities and kept available for treatments when necessary.

\section{MSCs conditioned medium}

It has been disclosed that MSCs secrete high amounts of cytokines, which induce inhibition of tumor growth, such as IFN- $\alpha$, IFN- $\beta$, IFN- $\gamma$, DKK-1/3, IL12, TRAIL (Tumor Necrosis-Factor-Related Apoptosis-Inducing Ligand), tumor necrosis factor superfamily member 14 (TNFSF14) also known as LIGHT, Fms-related tyrosine kinase 3 (FLT-3) ligand, C-X-C motif chemokine 10 (CXCL10) and liver-enriched transcriptional activator protein (LAP) [27, 30, 165, 175-178]. It has been also reported that the anti-tumor effect of MSCs may be partly related to the activity of the tissular inhibitors of matrix metalloproteinase (MMPs) TIMP-1 and TIMP-2, present in their secretome $[178,179]$, being the inhibition of MMPs associated with the inhibition of migration and invasion of cancer cells.

Interestingly, paracrine factors, collectively named as secretome, are estimated to be responsible for up to $80 \%$ of the therapeutic effect of MSCs. The heterogeneity of secretomes with respect to the tissue origin of MSCs is known. In this regard, we previously reported that hUCESCs-derived secretome produces higher antitumor cytokines than thoses from AD-MSCs. These antitumor citokines includes LIGHT, FLT-3, CXCL10 and LAP. On the contrary, several markers of tumor progression, such as epithelial growth factor receptor (EGFR), fibroblast growth factor (FGF), intercellular adhesion molecule 3 (ICAM3), interleukin-6 (IL-6), c-c motif ligand 7 (CCL-7), macrophage migration inhibitory factor (MIF), soluble glycoprotein 130 (sgp130) and vascular endothelial growth factor D (VEGF-D) are not detected or are lower in hUCESCs comparedto the secretome of ADMSCs (23). These differences in the composition of the secretomes may partially explain the different anti-tumor or pro-tumor effects of the MSCs according to their tissue origen. In this context, we may also consider that the anti-tumor acivity of AD-MSCs can be to a certain extent clarified by their high amounts of pro-angiogenic molecules [180] and MMPs [181] which secrete, whereas hUCESCs segregate large amounts of TIMP-1 and TIMP-2 [182].

However, the use of conditioned medium can have inconvenients, such as its scalable production, high salt content or being a poorly defined product, which can be a barrier for authorization by regulating agencies. An alternative for these problems could be the use of the EVs or exosomes present in these media.

\section{MSCs extracellular vesicles}

In general, it is assumed that MSCs-derived EVs perform similar functions to parent cells [183]. However, there are few studies on the basis of which we can evaluate the pro-tumor or anti-tumor effects of MSCs-derived EVs in accordance to their parent MSCs and pursuant to their different origins. In these few studies, for example, tEVs derived from BM-MSCs were shown to promote the growth of osteosarcoma and gastric cancerous cells (Table 1) [15], and inhibit the proliferation and promote apoptosis in liver carcinoma, Kaposi's sarcoma and ovarian tumor cell lines (Table 2) [22]. Meanwhile, EVs derived from AD-MSCs were exhibited to inhibit the growth of prostate cancer cells, ovarian cancerous cells and globlastoma Table 2) [23-25].

These findings seem to indicate a complex interaction of MSCs-derived EVs with tumor biology, which depend not only on the tissue origin of MSCs, but also on the type of tumor. Therefore, we must assume that further studies are required to better identify which MSCs produce the most appropriate EVs for each potential antitumor therapy.

Even so, MSCs are the only human cell type known that can be used for the mass production of EVs for drug delivery [184], maintaining the tumor homing ability [185]. EVs, including exosomes, are smaller, less complex and less immunogenic than their parent cells, since they have a lower content of membrane-bound proteins [186]. Furthermore, production and storage of EVs are easier than for their parental cells. In addition, other advantages of EVs include longer circulating half-time [187] or better crossing through the blood-brain barriers [188]. Also, EVs can be easily manipulated and can be modified with certain ligands or proteins on their surface in order to improve their targeting capability [189].

In order to enhance vesicle release from MSCs cells, several strategies have been proposed, such as prolonged culture and maintaining cells at low pH [190, 191]. The establishment of immortalized cells from MSCs is another strategy proposed to scale up EVs production [192], and, for instance, the overexpression of 
the oncogene $c-m y c$ has been reported to increase EVs production in MSCs [193].

On the other hand, MSCs-EVs have an additional interest for oncological therapy due to their tropism towards tumors, potentially behaving like "Trojan horses". Thus, it was shown that cancer cells internalize higher percentage of exosomes compared to normal cells $[160,161,194]$. The internalization of exosomes by cancer cells was also found to be 10 times greater than the internalization of liposomes of comparable size [160]. Furthermore, although the mechanism explaining the affinity of exosomes towards tumors is not yet well understood, it is known that the acid $\mathrm{pH}$ intratumor condition increases the internalization of exosomes [195], and also tumors are known to harbor a particularly acidic environment. This property of exosomes has raised their interest as carriers of antitumor factors.

Many types of "nanocarriers" have been developed in order to achieve the accumulation of anti-tumor agents to target cells (nano-gold particles, carbon nanotubes, molecules and liposomes, polymeric nanoparticles and polymer conjugates). Among those particles, the above-mentioned liposomes are the more effective ones. However, they have the drawback of causing immune rejection. For this reason, natural elements have been tested with tropism towards target cells, such as viruses, bacteria, erythrocytes, macrophages, lymphocytes, stem cells and exosomes. Among all of them, exosomes are the most promising natural carriers, due to their wide distribution by biological fluids and their intrinsic ability to search targets. [196, 197].

Exosomes can also be loaded with particles using different techniques, such as chemical transfection, incubation, electroporation, or by transfection of exosome-producing cells [198]. Regarding anti-cancer therapy, exosomes have been loaded with cytotoxic chemotherapy agents, small interefering RNA (siRNA) or miRNA.

It has been informed that MSCs-EVs loaded with paclitaxel, doxorubicin or gemcitabine reduce cell viability and inhibit oral squamous cancer cell growth [199]. In addition, exosomes loaded with methotrexate and functioned with a synthetic multifunctional peptide have also been shown to facilitate the membrane receptor mediated internalization procedure, both in vitro and in vivo in a glioma model [200]. In this line, it has also been shown that after treating several populations of human MSCs with sub-lethal concentrations of taxol for $24 \mathrm{~h}$, exosomes obtained showed $80 \%$ cytotoxicity against human lung, breast, or ovarian cancer cell lines. Likewise, these same microparticles intravenously administered caused a reduction of more than $60 \%$ of primary subcutaneous tumors and caused a significant reduction in metastasis in a xenograft model of these tumors in mice [201].

Exosomes transfected with different miRNA have demonstrated anti-tumor effects in different in vitro and in vivo models. For example, exosomes transfected with encapsulated miR-379 have been administered for breast cancer therapy in vivo with positive therapeutic effects [159]. Exosomes from mouse MSCs treated with miRNA133b suppress glioma progression [202], exosomes from umbilical cord MSCs transfected with miRNA-148-3p slow down breast cancer progression [203], exosomes from BM-MSCs transfected with miRNA-205 prevent the progression of prostate cancer [204], or exosomes from BM-MSCs transfected with miRNA-1231 inhibit the activity of the pancreatic cancer [205].

In line with this, it has also been reported that MSCsEVs loaded with siRNA can silence genes driving tumorigenesis. For example, MSCs-EX loaded with siRNA for polo-like kinase I decreased bladder cancer cell proliferation [161].

\section{Conclusions and future perspectives}

MSCs appear to play a central role in the context of intercellular signals between cancer cells and tumor stromal cells. We can consider the existence of cancer-educated MSCs that contribute to promote tumor progression, but also the possibility of MSCs not residing in the TME that may be an alternative to anti-tumor therapy. To establish this therapeutic hypothesis, we must start from the evidence indicating that the pro- or anti-tumor effect of MSCs will depend on the origin of the MSCs and the type of tumor. In this sense, the existing data seem to converge on the fact that MSCs originated in the uterus and pregnancy-related tissues have a broader antitumor effect, so they could be good candidates for oncological therapies. Likewise, products derived from the MSCs secretome, such as exosomes, can represent a good therapeutic strategy, avoiding the drawbacks related to direct cellular therapies. An additional advantage of these new biological products is the tropism towards tumors and their suitability to be manipulated in order to increase their effectiveness and potency. However, it is necessary to advance in the investigations that allow us to: (i) establish the most appropriate type of MSCs for each type of tumor; (ii) optimize the isolation and culture methods of these MSCs; (iii) define practical and reproducible methods for obtaining biological products of therapeutic interest derived from the secretome of these MSCs; and, (iv) identify the appropriate functional tests to measure these products prior to their application in patients. To achieve these goals, we must conveniently integrate technologies, such as cell culture techniques that include physical, chemical, biological and genetic manipulation, 
and the use of bioreactors, as well as the use of sophisticated extracellular vesicle isolation techniques, nanotechnology and artificial intelligence.

\section{Acknowledgements \\ Not applicable.}

\section{Authors' contributions}

All authors were involved in the writing of the manuscript. All authors read and approved the final manuscript.

\section{Funding}

This study was supported by grants to F.J.V. (PI17/02236) and to N.E. and F.J.V. (PI20/01122) from Instituto de Salud Carlos III and co-funded by European Union (ERDF/ESF, "Investing in your future") and by Fundación para la Investigación en Células Madre Uterinas (FICEMU) to F.J.V.

\section{Availability of data and materials}

Not applicable.

\section{Code availability}

Not applicable.

\section{Declarations}

\section{Ethics approval and consent to participate}

Not applicable.

\section{Consent for publication}

All authors agree with the content and all give explicit consent to submit this manuscript.

\section{Competing interests}

The authors declare the following competing interests: FJV and NE are coinventors of a patent ("Human uterine cervical stem cell population and uses thereof") owned by GiStem Research, of which NE, LAC and FJV are shareholders. The founding sponsors had no role in the design of this article, in the collection, analyses, or interpretation of data, in the writing of the manuscript, or in the decision to publish the results.

\section{Author details}

${ }^{1}$ Unit Research, Fundación Hospital de Jove, Avda. Eduardo Castro 161 33290 Gijón, Asturias, Spain. ${ }^{2}$ Department of Surgery, Fundación Hospital de Jove, 33290 Gijón, Asturias, Spain.

Received: 18 January 2021 Accepted: 31 May 2021

Published online: 10 June 2021

\section{References}

1. Eiro N, Gonzalez LO, Fraile M, Cid S, Schneider J, Vizoso FJ. Breast cancer tumor stroma: cellular components, phenotypic heterogeneity, intercellular communication, prognostic implications and therapeutic opportunities. Cancers (Basel). 2019. https://doi.org/10.3390/cance rs11050664.

2. Friedenstein AJ, Chailakhjan RK, Lalykina KS. The development of fibroblast colonies in monolayer cultures of guinea-pig bone marrow and spleen cells. Cell Tissue Kinet. 1970;3(4):393-403. https://doi.org/10. 1111/j.1365-2184.1970.tb00347.x.

3. Dominici M, Le Blanc K, Mueller I, Slaper-Cortenbach I, Marini F, Krause D, et al. Minimal criteria for defining multipotent mesenchymal stromal cells. The international society for cellular therapy position statement. Cytotherapy. 2006;8(4):315-7. https://doi.org/10.1080/1465324060 0855905.

4. Vizoso FJ, Eiro N, Costa L, Esparza P, Landin M, Diaz-Rodriguez P, et al. Mesenchymal stem cells in homeostasis and systemic diseases: hypothesis, evidences, and therapeutic opportunities. Int J Mol Sci. 2019. https://doi.org/10.3390/ijms20153738.
5. Samsonraj RM, Raghunath M, Nurcombe V, Hui JH, van Wijnen AJ, Cool SM. Concise review: multifaceted characterization of human mesenchymal stem cells for use in regenerative medicine. Stem Cells Transl Med. 2017;6(12):2173-85. https://doi.org/10.1002/sctm.17-0129.

6. Vizoso FJ, Eiro N, Cid S, Schneider J, Perez-Fernandez R. Mesenchymal stem cell secretome: toward cell-free therapeutic strategies in regenerative medicine. Int J Mol Sci. 2017. https://doi.org/10.3390/ijms1 8091852.

7. Dvorak HF. Tumors: wounds that do not heal. Similarities between tumor stroma generation and wound healing. N Engl J Med. 1986;315(26):1650-9. https://doi.org/10.1056/NEJM198612253152606.

8. Timaner M, Tsai KK, Shaked Y. The multifaceted role of mesenchymal stem cells in cancer. Semin Cancer Biol. 2020;60:225-37. https://doi.org/ 10.1016/j.semcancer.2019.06.003.

9. Francois S, Usunier B, Forgue-Lafitte ME, L'Homme B, Benderitter M, Douay $L$, et al. Mesenchymal stem cell administration attenuates colon cancer progression by modulating the immune component within the colorectal tumor microenvironment. Stem Cells Transl Med. 2019;8(3):285-300. https://doi.org/10.1002/sctm.18-0117.

10. Chaturvedi P, Gilkes DM, Wong CC, Kshitiz, Luo W, Zhang H, et al. Hypoxia-inducible factor-dependent breast cancer-mesenchymal stem cell bidirectional signaling promotes metastasis. J Clin Invest. 2013;123(1):189-205. https://doi.org/10.1172/JCl64993.

11. El-Haibi CP, Bell GW, Zhang J, Collmann AY, Wood D, Scherber CM, et al. Critical role for lysyl oxidase in mesenchymal stem cell-driven breast cancer malignancy. Proc Natl Acad Sci U S A. 2012;109(43):17460-5. https://doi.org/10.1073/pnas.1206653109.

12. Galoczova M, Coates P, Vojtesek B. STAT3, stem cells, cancer stem cells and p63. Cell Mol Biol Lett. 2018;23:12. https://doi.org/10.1186/ s11658-018-0078-0.

13. Patel SA, Meyer JR, Greco SJ, Corcoran KE, Bryan M, Rameshwar P. Mesenchymal stem cells protect breast cancer cells through regulatory T cells: role of mesenchymal stem cell-derived TGF-beta. J Immunol. 2010;184(10):5885-94. https://doi.org/10.4049/jimmunol.0903143.

14. Saito K, Sakaguchi M, Maruyama S, lioka H, Putranto EW, Sumardika IW, et al. Stromal mesenchymal stem cells facilitate pancreatic cancer progression by regulating specific secretory molecules through mutual cellular interaction. J Cancer. 2018;9(16):2916-29. https://doi.org/10. 7150/jca.24415.

15. Qi J, Zhou Y, Jiao Z, Wang X, Zhao Y, Li Y, et al. Exosomes derived from human bone marrow mesenchymal stem cells promote tumor growth through hedgehog signaling pathway. Cell Physiol Biochem. 2017;42(6):2242-54. https://doi.org/10.1159/000479998.

16. Walter M, Liang S, Ghosh S, Hornsby PJ, Li R. Interleukin 6 secreted from adipose stromal cells promotes migration and invasion of breast cancer cells. Oncogene. 2009;28(30):2745-55. https://doi.org/10.1038/onc. 2009.130.

17. Chandler EM, Seo BR, Califano JP, Andresen Eguiluz RC, Lee JS, Yoon CJ, et al. Implanted adipose progenitor cells as physicochemical regulators of breast cancer. Proc Natl Acad Sci U S A. 2012;109(25):9786-91. https://doi.org/10.1073/pnas.1121160109.

18. Xie C, Xie DY, Lin BL, Zhang GL, Wang PP, Peng L, et al. Interferon-beta gene-modified human bone marrow mesenchymal stem cells attenuate hepatocellular carcinoma through inhibiting AKT/FOXO3a pathway. Br J Cancer. 2013;109(5):1198-205. https://doi.org/10.1038/bjc.2013. 422.

19. Ho IA, Toh HC, Ng WH, Teo YL, Guo CM, Hui KM, et al. Human bone marrow-derived mesenchymal stem cells suppress human glioma growth through inhibition of angiogenesis. Stem Cells. 2013;31(1):14655. https://doi.org/10.1002/stem.1247.

20. Meleshina AV, Cherkasova El, Shirmanova MV, Klementieva NV, Kiseleva EV, Snopova LB, et al. Influence of mesenchymal stem cells on metastasis development in mice in vivo. Stem Cell Res Ther. 2015;6:15. https:// doi.org/10.1186/s13287-015-0003-7.

21. Attar-Schneider O, Zismanov V, Drucker L, Gottfried M. Secretome of human bone marrow mesenchymal stem cells: an emerging player in lung cancer progression and mechanisms of translation initiation. Tumour Biol. 2016;37(4):4755-65. https://doi.org/10.1007/ s13277-015-4304-3.

22. Costa LA, Eiro N, Fraile M, Gonzalez LO, Saa J, Garcia-Portabella P, et al. Functional heterogeneity of mesenchymal stem cells from 
natural niches to culture conditions: implications for further clinical uses. Cell Mol Life Sci. 2021;78(2):447-67. https://doi.org/10.1007/ s00018-020-03600-0.

23. Reza A, Choi YJ, Yasuda H, Kim JH. Human adipose mesenchymal stem cell-derived exosomal-miRNAs are critical factors for inducing antiproliferation signalling to A2780 and SKOV-3 ovarian cancer cells. Sci Rep. 2016;6:38498. https://doi.org/10.1038/srep38498.

24. Pacioni S, D'Alessandris QG, Giannetti S, Morgante L, Cocce V, Bonomi A, et al. Human mesenchymal stromal cells inhibit tumor growth in orthotopic glioblastoma xenografts. Stem Cell Res Ther. 2017;8(1):53. https://doi.org/10.1186/s13287-017-0516-3.

25. Takahara K, li M, Inamoto T, Nakagawa T, Ibuki N, Yoshikawa Y, et al. microRNA-145 mediates the inhibitory effect of adipose tissue-derived stromal cells on prostate cancer. Stem Cells Dev. 2016;25(17):1290-8. https://doi.org/10.1089/scd.2016.0093.

26. Bu S, Wang Q, Zhang Q, Sun J, He B, Xiang C, et al. Human endometrial mesenchymal stem cells exhibit intrinsic anti-tumor properties on human epithelial ovarian cancer cells. Sci Rep. 2016;6:37019. https://doi. org/10.1038/srep37019.

27. Eiro N, Sendon-Lago J, Seoane S, Bermudez MA, Lamelas ML, GarciaCaballero T, et al. Potential therapeutic effect of the secretome from human uterine cervical stem cells against both cancer and stromal cells compared with adipose tissue stem cells. Oncotarget. 2014;5(21):10692-708. https://doi.org/10.18632/oncotarget.2530.

28. Gholizadeh-Ghaleh Aziz S, Fardyazar Z, Pashaiasl M. The human amniotic fluid mesenchymal stem cells therapy on, SKOV3, ovarian cancer cell line. Mol Genet Genomic Med. 2019;7(7):e00726. https://doi.org/10. 1002/mgg3.726.

29. Alshareeda AT, Rakha E, Alghwainem A, Alrfaei B, Alsowayan B, Albugami A, et al. The effect of human placental chorionic villi derived mesenchymal stem cell on triple-negative breast cancer hallmarks. PLoS ONE. 2018;13(11):e0207593. https://doi.org/10.1371/journal.pone. 0207593.

30. Leng L, Wang Y, He N, Wang D, Zhao Q, Feng G, et al. Molecular imaging for assessment of mesenchymal stem cells mediated breast cancer therapy. Biomaterials. 2014;35(19):5162-70. https://doi.org/10.1016/j. biomaterials.2014.03.014.

31. Wu N, Zhang YL, Wang HT, Li DW, Dai HJ, Zhang QQ, et al. Overexpression of hepatocyte nuclear factor 4alpha in human mesenchymal stem cells suppresses hepatocellular carcinoma development through Wnt/ beta-catenin signaling pathway downregulation. Cancer Biol Ther. 2016:17(5):558-65. https://doi.org/10.1080/15384047.2016.1177675.

32. Dasari VR, Kaur K, Velpula KK, Gujrati M, Fassett D, Klopfenstein JD, et al. Upregulation of PTEN in glioma cells by cord blood mesenchymal stem cells inhibits migration via downregulation of the PI3K/Akt pathway. PLOS ONE. 2010;5(4):e10350. https://doi.org/10.1371/journal.pone. 0010350.

33. Mirabdollahi M, Haghjooyjavanmard S, Sadeghi-Aliabadi H. An anticancer effect of umbilical cord-derived mesenchymal stem cell secretome on the breast cancer cell line. Cell Tissue Bank. 2019;20(3):423-34. https://doi.org/10.1007/s10561-019-09781-8.

34. Kalamegam G, Sait KHW, Ahmed F, Kadam R, Pushparaj PN, Anfinan N, et al. Human Wharton's Jelly Stem Cell (hWJSC) extracts inhibit ovarian cancer cell lines OVCAR3 and SKOV3 in vitro by inducing cell cycle arrest and apoptosis. Front Oncol. 2018;8:592. https://doi.org/10.3389/ fonc.2018.00592.

35. Gauthaman K, Fong CY, Arularasu S, Subramanian A, Biswas A, Choolani $M$, et al. Human Wharton's jelly stem cell conditioned medium and cellfree lysate inhibit human osteosarcoma and mammary carcinoma cell growth in vitro and in xenograft mice. J Cell Biochem. 2013;114(2):36677. https://doi.org/10.1002/jcb.24367.

36. Han KH, Kim AK, Jeong GJ, Jeon HR, Bhang SH, Kim DI. Enhanced anticancer effects of conditioned medium from hypoxic human umbilical cord-derived mesenchymal stem cells. Int J Stem Cells. 2019;12(2):291303. https://doi.org/10.15283/ijsc19002.

37. He N, Kong Y, Lei X, Liu Y, Wang J, Xu C, et al. MSCs inhibit tumor progression and enhance radiosensitivity of breast cancer cells by downregulating Stat3 signaling pathway. Cell Death Dis. 2018;9(10):1026. https://doi.org/10.1038/s41419-018-0949-3.

38. Nakagawa H, Liyanarachchi S, Davuluri RV, Auer H, Martin EW Jr, de la Chapelle A, et al. Role of cancer-associated stromal fibroblasts in metastatic colon cancer to the liver and their expression profiles. Oncogene. 2004;23(44):7366-77. https://doi.org/10.1038/sj.onc.1208013.

39. Arena S, Salati M, Sorgentoni G, Barbisan F, Orciani M. Characterization of tumor-derived mesenchymal stem cells potentially differentiating into cancer-associated fibroblasts in lung cancer. Clin Transl Oncol. 2018;20(12):1582-91. https://doi.org/10.1007/s12094-018-1894-4.

40. Shangguan L, Ti X, Krause U, Hai B, Zhao Y, Yang Z, et al. Inhibition of TGF-beta/Smad signaling by BAMBI blocks differentiation of human mesenchymal stem cells to carcinoma-associated fibroblasts and abolishes their protumor effects. Stem Cells. 2012;30(12):2810-9. https://doi. org/10.1002/stem.1251.

41. Annaratone L, Cascardi E, Vissio E, Sarotto I, Chmielik E, Sapino A, et al. The multifaceted nature of tumor microenvironment in breast carcinomas. Pathobiology. 2020;87(2):125-42. https://doi.org/10.1159/00050 7055.

42. Choi J, Cha YJ, Koo JS. Adipocyte biology in breast cancer: From silent bystander to active facilitator. Prog Lipid Res. 2018;69:11-20. https://doi. org/10.1016/j.plipres.2017.11.002.

43. Hanahan D, Weinberg RA. The hallmarks of cancer. Cell. 2000;100(1):5770. https://doi.org/10.1016/s0092-8674(00)81683-9.

44. Burlacu A, Grigorescu G, Rosca AM, Preda MB, Simionescu M. Factors secreted by mesenchymal stem cells and endothelial progenitor cells have complementary effects on angiogenesis in vitro. Stem Cells Dev. 2013;22(4):643-53. https://doi.org/10.1089/scd.2012.0273.

45. Suzuki K, Sun R, Origuchi M, Kanehira M, Takahata T, Itoh J, et al. Mesenchymal stromal cells promote tumor growth through the enhancement of neovascularization. Mol Med. 2011;17(7-8):579-87. https://doi. org/10.2119/molmed.2010.00157.

46. Zhu W, Huang L, Li Y, Zhang X, Gu J, Yan Y, et al. Exosomes derived from human bone marrow mesenchymal stem cells promote tumor growth in vivo. Cancer Lett. 2012;315(1):28-37. https://doi.org/10.1016/j.canlet. 2011.10.002.

47. Bexell D, Gunnarsson S, Tormin A, Darabi A, Gisselsson D, Roybon L, et al. Bone marrow multipotent mesenchymal stroma cells act as pericyte-like migratory vehicles in experimental gliomas. Mol Ther. 2009;17(1):183-90. https://doi.org/10.1038/mt.2008.229.

48. Spaeth EL, Dembinski JL, Sasser AK, Watson K, Klopp A, Hall B, et al. Mesenchymal stem cell transition to tumor-associated fibroblasts contributes to fibrovascular network expansion and tumor progression. PLoS ONE. 2009;4(4):e4992. https://doi.org/10.1371/journal.pone.00049 92.

49. Tsai KS, Yang SH, Lei YP, Tsai CC, Chen HW, Hsu CY, et al. Mesenchymal stem cells promote formation of colorectal tumors in mice. Gastroenterology. 2011;141(3):1046-56. https://doi.org/10.1053/j.gastro.2011.05. 045.

50. Boomsma RA, Geenen DL. Mesenchymal stem cells secrete multiple cytokines that promote angiogenesis and have contrasting effects on chemotaxis and apoptosis. PLOS ONE. 2012;7(4):e35685. https://doi.org/ 10.1371/journal.pone.0035685.

51. Zhang T, Lee YW, Rui YF, Cheng TY, Jiang XH, Li G. Bone marrow-derived mesenchymal stem cells promote growth and angiogenesis of breast and prostate tumors. Stem Cell Res Ther. 2013;4(3):70. https://doi.org/ $10.1186 /$ scrt221.

52. Du WJ, Chi Y, Yang ZX, Li ZJ, Cui JJ, Song BQ, et al. Heterogeneity of proangiogenic features in mesenchymal stem cells derived from bone marrow, adipose tissue, umbilical cord, and placenta. Stem Cell Res Ther. 2016;7(1):163. https://doi.org/10.1186/s13287-016-0418-9.

53. Zanotti L, Angioni R, Cali B, Soldani C, Ploia C, Moalli F, et al. Mouse mesenchymal stem cells inhibit high endothelial cell activation and lymphocyte homing to lymph nodes by releasing TIMP-1. Leukemia. 2016;30(5):1143-54. https://doi.org/10.1038/leu.2016.33.

54. Almendros I, Gozal D. Intermittent hypoxia and cancer: Undesirable bed partners? Respir Physiol Neurobiol. 2018;256:79-86. https://doi.org/10. 1016/j.resp.2017.08.008

55. Wang M, Yuan Q, Xie L. Mesenchymal stem cell-based immunomodulation: properties and clinical application. Stem Cells Int. 2018;2018:3057624. https://doi.org/10.1155/2018/3057624.

56. Batten P, Sarathchandra P, Antoniw JW, Tay SS, Lowdell MW, Taylor $\mathrm{PM}$, et al. Human mesenchymal stem cells induce T cell anergy and downregulate $\mathrm{T}$ cell allo-responses via the TH2 pathway: relevance to 
tissue engineering human heart valves. Tissue Eng. 2006;12(8):2263-73. https://doi.org/10.1089/ten.2006.12.2263.

57. Sato K, Ozaki K, Oh I, Meguro A, Hatanaka K, Nagai T, et al. Nitric oxide plays a critical role in suppression of T-cell proliferation by mesenchymal stem cells. Blood. 2007;109(1):228-34. https://doi.org/10.1182/ blood-2006-02-002246.

58. Rivera-Cruz CM, Shearer JJ, Figueiredo Neto M, Figueiredo ML. The immunomodulatory effects of mesenchymal stem cell polarization within the tumor microenvironment niche. Stem Cells Int. 2017;2017:4015039. https://doi.org/10.1155/2017/4015039.

59. Poggi A, Varesano S, Zocchi MR. How to hit mesenchymal stromal cells and make the tumor microenvironment immunostimulant rather than immunosuppressive. Front Immunol. 2018;9:262. https://doi.org/10. 3389/fimmu.2018.00262.

60. Hu X, Zhou Y, Dong K, Sun Z, Zhao D, Wang W, et al. Programming of the development of tumor-promoting neutrophils by mesenchymal stromal cells. Cell Physiol Biochem. 2014;33(6):1802-14. https://doi.org/ 10.1159/000362959.

61. Zhu Q, Zhang X, Zhang L, Li W, Wu H, Yuan X, et al. The IL-6-STAT3 axis mediates a reciprocal crosstalk between cancer-derived mesenchymal stem cells and neutrophils to synergistically prompt gastric cancer progression. Cell Death Dis. 2014;5:e1295. https://doi.org/10.1038/cddis. 2014.263.

62. Gao WX, Sun YQ, Shi J, Li CL, Fang SB, Wang D, et al. Effects of mesenchymal stem cells from human induced pluripotent stem cells on differentiation, maturation, and function of dendritic cells. Stem Cell Res Ther. 2017:8(1):48. https://doi.org/10.1186/s13287-017-0499-0.

63. Spaggiari GM, Abdelrazik H, Becchetti F, Moretta L. MSCs inhibit monocyte-derived DC maturation and function by selectively interfering with the generation of immature DCs: central role of MSC-derived prostaglandin E2. Blood. 2009;113(26):6576-83. https://doi.org/10, 1182/blood-2009-02-203943.

64. Han Z, Tian Z, Lv G, Zhang L, Jiang G, Sun K, et al. Immunosuppressive effect of bone marrow-derived mesenchymal stem cells in inflammatory microenvironment favours the growth of B16 melanoma cells. $J$ Cell Mol Med. 2011;15(11):2343-52. https://doi.org/10.1111/j.15824934.2010.01215.x.

65. Sotiropoulou PA, Perez SA, Gritzapis AD, Baxevanis CN, Papamichail M. Interactions between human mesenchymal stem cells and natural killer cells. Stem Cells. 2006;24(1):74-85. https://doi.org/10.1634/stemcells. 2004-0359.

66. Galland S, Vuille J, Martin P, Letovanec I, Caignard A, Fregni G, et al. Tumor-derived mesenchymal stem cells use distinct mechanisms to block the activity of natural killer cell subsets. Cell Rep. 2017;20(12):2891-905. https://doi.org/10.1016/j.celrep.2017.08.089.

67. Duffy MM, Ritter T, Ceredig R, Griffin MD. Mesenchymal stem cell effects on T-cell effector pathways. Stem Cell Res Ther. 2011;2(4):34. https://doi. org/10.1186/scrt75.

68. Niu J, Yue W, Le-Le Z, Bin L, Hu X. Mesenchymal stem cells inhibitT cell activation by releasing TGF-beta1 from TGF-beta1/GARP complex. Oncotarget. 2017:8(59):99784-800. https://doi.org/10.18632/oncot arget.21549.

69. Akiyama K, Chen C, Wang D, Xu X, Qu C, Yamaza T, et al. Mesenchymalstem-cell-induced immunoregulation involves FAS-ligand-/FAS-mediated T cell apoptosis. Cell Stem Cell. 2012;10(5):544-55. https://doi.org/ 10.1016/j.stem.2012.03.007.

70. O'Connor BP, Vogel LA, Zhang W, Loo W, Shnider D, Lind EF, et al. Imprinting the fate of antigen-reactive $B$ cells through the affinity of the B cell receptor. J Immunol. 2006;177(11):7723-32. https://doi.org/10 4049/jimmunol.177.11.7723.

71. Uccelli A, Moretta L, Pistoia V. Mesenchymal stem cells in health and disease. Nat Rev Immunol. 2008:8(9):726-36. https://doi.org/10.1038/ nri2395.

72. Asari S, Itakura S, Ferreri K, Liu CP, Kuroda Y, Kandeel F, et al. Mesenchymal stem cells suppress B-cell terminal differentiation. Exp Hematol. 2009:37(5):604-15. https://doi.org/10.1016/j.exphem.2009.01.005.

73. Ungerer C, Quade-Lyssy P, Radeke HH, Henschler R, Konigs C, Kohl $U$, et al. Galectin-9 is a suppressor of T and B cells and predicts the immune modulatory potential of mesenchymal stromal cell preparations. Stem Cells Dev. 2014;23(7):755-66. https://doi.org/10.1089/scd. 2013.0335 .
74. Vasandan AB, Jahnavi S, Shashank C, Prasad P, Kumar A, Prasanna SJ. Human Mesenchymal stem cells program macrophage plasticity by altering their metabolic status via a PGE2-dependent mechanism. Sci Rep. 2016;6:38308. https://doi.org/10.1038/srep38308.

75. Nemeth K, Leelahavanichkul A, Yuen PS, Mayer B, Parmelee A, Doi K, et al. Bone marrow stromal cells attenuate sepsis via prostaglandin $E(2)$-dependent reprogramming of host macrophages to increase their interleukin-10 production. Nat Med. 2009;15(1):42-9. https://doi.org/10. 1038/nm.1905

76. Chen B, Ni Y, Liu J, Zhang Y, Yan F. Bone marrow-derived mesenchymal stem cells exert diverse effects on different macrophage subsets. Stem Cells Int. 2018;2018:8348121. https://doi.org/10.1155/2018/8348121.

77. Lee HJ, Ko JH, Jeong HJ, Ko AY, Kim MK, Wee WR, et al. Mesenchymal stem/stromal cells protect against autoimmunity via CCL2-dependent recruitment of myeloid-derived suppressor cells. J Immunol. 2015;194(8):3634-45. https://doi.org/10.4049/jimmunol.1402139.

78. Efimenko A, Starostina E, Kalinina N, Stolzing A. Angiogenic properties of aged adipose derived mesenchymal stem cells after hypoxic conditioning. J Transl Med. 2011;9:10. https://doi.org/10.1186/ 1479-5876-9-10.

79. Hung SC, Pochampally RR, Chen SC, Hsu SC, Prockop DJ. Angiogenic effects of human multipotent stromal cell conditioned medium activate the PI3K-Akt pathway in hypoxic endothelial cells to inhibit apoptosis, increase survival, and stimulate angiogenesis. Stem Cells. 2007;25(9):2363-70. https://doi.org/10.1634/stemcells.2006-0686.

80. Crisostomo PR, Wang Y, Markel TA, Wang M, Lahm T, Meldrum DR. Human mesenchymal stem cells stimulated by TNF-alpha, LPS, or hypoxia produce growth factors by an NF kappa B- but not JNKdependent mechanism. Am J Physiol Cell Physiol. 2008;294(3):C675682. https://doi.org/10.1152/ajpcell.00437.2007.

81. Yang J, Antin P, Berx G, Blanpain C, Brabletz T, Bronner M, et al. Guidelines and definitions for research on epithelial-mesenchymal transition. Nat Rev Mol Cell Biol. 2020;21(6):341-52. https://doi.org/10.1038/ s41580-020-0237-9.

82. Bates RC, Mercurio AM. Tumor necrosis factor-alpha stimulates the epithelial-to-mesenchymal transition of human colonic organoids. Mol Biol Cell. 2003;14(5):1790-800. https://doi.org/10.1091/mbc. e02-09-0583.

83. Martin FT, Dwyer RM, Kelly J, Khan S, Murphy JM, Curran C, et al. Potential role of mesenchymal stem cells (MSCs) in the breast tumour microenvironment: stimulation of epithelial to mesenchymal transition (EMT). Breast Cancer Res Treat. 2010;124(2):317-26. https://doi.org/10. 1007/s10549-010-0734-1.

84. Xue Z, Wu X, Chen X, Liu Y, Wang X, Wu K, et al. Mesenchymal stem cells promote epithelial to mesenchymal transition and metastasis in gastric cancer though paracrine cues and close physical contact. J Cell Biochem. 2015;1 16(4):618-27. https://doi.org/10.1002/jcb.25013.

85. Karnoub AE, Dash AB, Vo AP, Sullivan A, Brooks MW, Bell GW, et al. Mesenchymal stem cells within tumour stroma promote breast cancer metastasis. Nature. 2007;449(7162):557-63. https://doi.org/10.1038/ nature06188.

86. Reya T, Morrison SJ, Clarke MF, Weissman IL. Stem cells, cancer, and cancer stem cells. Nature. 2001:414(6859):105-11. https://doi.org/10. 1038/35102167.

87. Hsu HS, Lin JH, Hsu TW, Su K, Wang CW, Yang KY, et al. Mesenchymal stem cells enhance lung cancer initiation through activation of IL-6/ JAK2/STAT3 pathway. Lung Cancer. 2012;75(2):167-77. https://doi.org/ 10.1016/j.lungcan.2011.07.001.

88. Liu S, Ginestier C, Ou SJ, Clouthier SG, Patel SH, Monville F, et al. Breast cancer stem cells are regulated by mesenchymal stem cells through cytokine networks. Cancer Res. 2011;71(2):614-24. https://doi.org/10. 1158/0008-5472.CAN-10-0538.

89. Maffey A, Storini C, Diceglie C, Martelli C, Sironi L, Calzarossa C, et al. Mesenchymal stem cells from tumor microenvironment favour breast cancer stem cell proliferation, cancerogenic and metastatic potential, via ionotropic purinergic signalling. Sci Rep. 2017;7(1):13162. https:// doi.org/10.1038/s41598-017-13460-7.

90. Nishimura K, Semba S, Aoyagi K, Sasaki H, Yokozaki H. Mesenchymal stem cells provide an advantageous tumor microenvironment for the restoration of cancer stem cells. Pathobiology. 2012;79(6):290-306. https://doi.org/10.1159/000337296. 
91. Coffman LG, Choi YJ, McLean K, Allen BL, di Magliano MP, Buckanovich RJ. Human carcinoma-associated mesenchymal stem cells promote ovarian cancer chemotherapy resistance via a BMP4/HH signaling loop. Oncotarget. 2016;7(6):6916-32. https://doi.org/10.18632/oncotarget. 6870

92. Ma X, Liu J, Yang $X$, Fang $K$, Zheng $P$, Liang $X$, et al. Mesenchymal stem cells maintain the stemness of colon cancer stem cells via interleukin-8/ mitogen-activated protein kinase signaling pathway. Exp Biol Med (Maywood). 2020;245(6):562-75. https://doi.org/10.1177/1535370220 910690.

93. Houghton J, Stoicov C, Nomura S, Rogers AB, Carlson J, Li H, et al. Gastric cancer originating from bone marrow-derived cells. Science. 2004;306(5701):1568-71. https://doi.org/10.1126/science.1099513.

94. Rodini CO, Goncalves da Silva PB, Assoni AF, Carvalho VM, Okamoto OK. Mesenchymal stem cells enhance tumorigenic properties of human glioblastoma through independent cell-cell communication mechanisms. Oncotarget. 2018;9(37):24766-77. https://doi.org/10.18632/ oncotarget.25346.

95. McAndrews KM, McGrail DJ, Ravikumar N, Dawson MR. Mesenchymal stem cells induce directional migration of invasive breast cancer cells through TGF-beta. Sci Rep. 2015;5:16941. https://doi.org/10.1038/srep1 6941.

96. Ma M, Ye JY, Deng R, Dee CM, Chan GC. Mesenchymal stromal cells may enhance metastasis of neuroblastoma via SDF-1/CXCR4 and SDF-1/ CXCR7 signaling. Cancer Lett. 2011;312(1):1-10. https://doi.org/10. 1016/j.canlet.2011.06.028.

97. Eckert F, Schilbach K, Klumpp L, Bardoscia L, Sezgin EC, Schwab M, et al. Potential role of CXCR4 targeting in the context of radiotherapy and immunotherapy of cancer. Front Immunol. 2018;9:3018. https://doi.org/ 10.3389/fimmu.2018.03018.

98. Reagan MR, Rosen CJ. Navigating the bone marrow niche: translational insights and cancer-driven dysfunction. Nat Rev Rheumatol. 2016;12(3):154-68. https://doi.org/10.1038/nrrheum.2015.160.

99. Moitra K. Overcoming multidrug resistance in cancer stem cells. Biomed Res Int. 2015;2015:635745. https://doi.org/10.1155/2015/ 635745.

100. Timaner M, Letko-Khait N, Kotsofruk R, Benguigui M, Beyar-Katz O, Rachman-Tzemah C, et al. Therapy-educated mesenchymal stem cells enrich for tumor-initiating cells. Cancer Res. 2018;78(5):1253-65. https://doi. org/10.1158/0008-5472.CAN-17-1547.

101. Skolekova S, Matuskova M, Bohac M, Toro L, Durinikova E, Tyciakova $\mathrm{S}$, et al. Cisplatin-induced mesenchymal stromal cells-mediated mechanism contributing to decreased antitumor effect in breast cancer cells. Cell Commun Signal. 2016;14:4. https://doi.org/10.1186/ s12964-016-0127-0.

102. Gilbert LA, Hemann MT. DNA damage-mediated induction of a chemoresistant niche. Cell. 2010;143(3):355-66. https://doi.org/10.1016/j.cell. 2010.09.043.

103. Scherzed A, Hackenberg S, Froelich K, Kessler M, Koehler C, Hagen R, et al. BMSC enhance the survival of paclitaxel treated squamous cell carcinoma cells in vitro. Cancer Biol Ther. 2011;11(3):349-57. https://doi. org/10.4161/cbt.11.3.14179.

104. Vianello F, Villanova F, Tisato V, Lymperi S, Ho KK, Gomes AR, et al. Bone marrow mesenchymal stromal cells non-selectively protect chronic myeloid leukemia cells from imatinib-induced apoptosis via the CXCR4/ CXCL12 axis. Haematologica. 2010;95(7):1081-9. https://doi.org/10. 3324/haematol.2009.017178.

105. Lis R, Touboul C, Mirshahi P, Ali F, Mathew S, Nolan DJ, et al. Tumor associated mesenchymal stem cells protects ovarian cancer cells from hyperthermia through CXCL12. Int J Cancer. 2011;128(3):715-25. https://doi.org/10.1002/ijc.25619.

106. Balakrishnan K, Burger JA, Quiroga MP, Henneberg M, Ayres ML, Wierda WG, et al. Influence of bone marrow stromal microenvironment on forodesine-induced responses in CLL primary cells. Blood. 2010;116(7):1083-91. https://doi.org/10.1182/blood-2009-10-246199.

107. Roodhart JM, Daenen LG, Stigter EC, Prins HJ, Gerrits J, Houthuijzen $J \mathrm{M}$, et al. Mesenchymal stem cells induce resistance to chemotherapy through the release of platinum-induced fatty acids. Cancer Cell. 2011;20(3):370-83. https://doi.org/10.1016/j.ccr.2011.08.010.

108. Houthuijzen JM, Daenen LG, Roodhart JM, Voest EE. The role of mesenchymal stem cells in anti-cancer drug resistance and tumour progression. Br J Cancer. 2012;106(12):1901-6. https://doi.org/10.1038/ bjc.2012.201.

109. Qiao L, Xu ZL, Zhao TJ, Ye LH, Zhang XD. Dkk-1 secreted by mesenchymal stem cells inhibits growth of breast cancer cells via depression of Wnt signalling. Cancer Lett. 2008;269(1):67-77. https://doi.org/10. 1016/j.canlet.2008.04.032.

110. Zhu Y, Sun Z, Han Q, Liao L, Wang J, Bian C, et al. Human mesenchymal stem cells inhibit cancer cell proliferation by secreting DKK-1. Leukemia. 2009;23(5):925-33. https://doi.org/10.1038/leu.2008.384.

111. Ji X, Zhang Z, Han Y, Song J, Xu X, Jin J, et al. Mesenchymal stem cells derived from normal gingival tissue inhibit the proliferation of oral cancer cells in vitro and in vivo. Int J Oncol. 2016;49(5):2011-22. https:// doi.org/10.3892/ijo.2016.3715.

112. Ryu H, Oh JE, Rhee KJ, Baik SK, Kim J, Kang SJ, et al. Adipose tissuederived mesenchymal stem cells cultured at high density express IFN-beta and suppress the growth of MCF-7 human breast cancer cells. Cancer Lett. 2014;352(2):220-7. https://doi.org/10.1016/j.canlet.2014.06. 018.

113. Ridge SM, Sullivan FJ, Glynn SA. Mesenchymal stem cells: key players in cancer progression. Mol Cancer. 2017;16(1):31. https://doi.org/10.1186/ s12943-017-0597-8.

114. Melzer C, Yang Y, Hass R. Interaction of MSC with tumor cells. Cell Commun Signal. 2016;14(1):20. https://doi.org/10.1186/s12964-016-0143-0.

115. Norozi F, Ahmadzadeh A, Shahrabi S, Vosoughi T, Saki N. Mesenchymal stem cells as a double-edged sword in suppression or progression of solid tumor cells. Tumour Biol. 2016;37(9):11679-89. https://doi.org/10. 1007/s13277-016-5187-7.

116. Ohlsson LB, Varas L, Kjellman C, Edvardsen K, Lindvall M. Mesenchymal progenitor cell-mediated inhibition of tumor growth in vivo and in vitro in gelatin matrix. Exp Mol Pathol. 2003;75(3):248-55. https://doi.org/10. 1016/j.yexmp.2003.06.001.

117. Zheng H, Zou W, Shen J, Xu L, Wang S, Fu YX, et al. Opposite effects of coinjection and distant injection of mesenchymal stem cells on breast tumor cell growth. Stem Cells Transl Med. 2016;5(9):1216-28. https:// doi.org/10.5966/sctm.2015-0300.

118. Cassatella MA, Mosna F, Micheletti A, Lisi V, Tamassia N, Cont C, et al. Toll-like receptor-3-activated human mesenchymal stromal cells significantly prolong the survival and function of neutrophils. Stem Cells. 2011;29(6):1001-11. https://doi.org/10.1002/stem.651.

119. Stagg J, Pommey S, Eliopoulos N, Galipeau J. Interferon-gammastimulated marrow stromal cells: a new type of nonhematopoietic antigen-presenting cell. Blood. 2006;107(6):2570-7. https://doi.org/10. 1182/blood-2005-07-2793.

120. Erez N, Truitt M, Olson P, Arron ST, Hanahan D. Cancer-Associated fibroblasts are activated in incipient neoplasia to orchestrate tumorpromoting inflammation in an NF-kappaB-dependent manner. Cancer Cell. 2010;17(2):135-47. https://doi.org/10.1016/j.ccr.2009.12.041.

121. Wong RS. Mesenchymal stem cells: angels or demons? J Biomed Biotechnol. 2011;2011:459510. https://doi.org/10.1155/2011/459510.

122. Hong IS, Lee HY, Kang KS. Mesenchymal stem cells and cancer: friends or enemies? Mutat Res. 2014;768:98-106. https://doi.org/10.1016/j. mrfmmm.2014.01.006.

123. Lin $W$, Huang L, Li Y, Fang B, Li G, Chen L, et al. Mesenchymal stem cells and cancer: clinical challenges and opportunities. Biomed Res Int. 2019:2019:2820853. https://doi.org/10.1155/2019/2820853.

124. Rhee KJ, Lee Jl, Eom YW. Mesenchymal stem cell-mediated effects of tumor support or suppression. Int J Mol Sci. 2015;16(12):30015-33. https://doi.org/10.3390/ijms161226215.

125. Lin HD, Fong CY, Biswas A, Choolani M, Bongso A. Human Wharton's jelly stem cells, its conditioned medium and cell-free lysate inhibit the growth of human lymphoma cells. Stem Cell Rev Rep. 2014;10(4):57386. https://doi.org/10.1007/s12015-014-9514-3.

126. Bermudez MA, Sendon-Lago J, Seoane S, Eiro N, Gonzalez F, Saa J, et al. Anti-inflammatory effect of conditioned medium from human uterine cervical stem cells in uveitis. Exp Eye Res. 2016;149:84-92. https://doi. org/10.1016/j.exer.2016.06.022.

127. Bermudez MA, Sendon-Lago J, Eiro N, Trevino M, Gonzalez F, YebraPimentel E, et al. Corneal epithelial wound healing and bactericidal effect of conditioned medium from human uterine cervical stem cells. Invest Ophthalmol Vis Sci. 2015;56(2):983-92. https://doi.org/10.1167/ iovs.14-15859. 
128. Schneider J, Mateo E, Marcos-Arias C, Eiro N, Vizoso F, Perez-Fernandez $\mathrm{R}$, et al. Antifungal activity of the human uterine cervical stem cells conditioned medium (hUCESC-CM) against candida albicans and other medically relevant species of candida. Front Microbiol. 2018;9:2818. https://doi.org/10.3389/fmicb.2018.02818.

129. Yuan Y, Jiang YC, Sun CK, Chen QM. Role of the tumor microenvironment in tumor progression and the clinical applications (Review). Oncol Rep. 2016;35(5):2499-515. https://doi.org/10.3892/or.2016.4660.

130. Popivanova BK, Kostadinova FI, Furuichi K, Shamekh MM, Kondo T, Wada T, et al. Blockade of a chemokine, CCL2, reduces chronic colitisassociated carcinogenesis in mice. Cancer Res. 2009;69(19):7884-92. https://doi.org/10.1158/0008-5472.CAN-09-1451.

131. Harper J, Sainson RC. Regulation of the anti-tumour immune response by cancer-associated fibroblasts. Semin Cancer Biol. 2014;25:69-77. https://doi.org/10.1016/j.semcancer.2013.12.005.

132. Cocucci E, Meldolesi J. Ectosomes and exosomes: shedding the confusion between extracellular vesicles. Trends Cell Biol. 2015;25(6):364-72. https://doi.org/10.1016/j.tcb.2015.01.004.

133. Abels ER, Breakefield XO. Introduction to extracellular vesicles: biogenesis, RNA cargo selection, content, release, and uptake. Cell Mol Neurobiol. 2016;36(3):301-12. https://doi.org/10.1007/s10571-016-0366-z.

134. Boyiadzis $M$, Whiteside TL. The emerging roles of tumor-derived exosomes in hematological malignancies. Leukemia. 2017;31(6):125968. https://doi.org/10.1038/leu.2017.91.

135. Ludwig S, Floros T, Theodoraki MN, Hong CS, Jackson EK, Lang S, et al. Suppression of lymphocyte functions by plasma exosomes correlates with disease activity in patients with head and neck cancer. Clin Cancer Res. 2017;23(16):4843-54. https://doi.org/10.1158/1078-0432. CCR-16-2819.

136. Hong CS, Funk S, Muller L, Boyiadzis M, Whiteside TL. Isolation of biologically active and morphologically intact exosomes from plasma of patients with cancer. J Extracell Vesicles. 2016;5:29289. https://doi.org/ 10.3402/jev.v5.29289.

137. Boyiadzis M, Whiteside TL. Information transfer by exosomes: A new frontier in hematologic malignancies. Blood Rev. 2015;29(5):281-90. https://doi.org/10.1016/j.blre.2015.01.004.

138. Lindoso RS, Collino F, Camussi G. Extracellular vesicles derived from renal cancer stem cells induce a pro-tumorigenic phenotype in mesenchymal stromal cells. Oncotarget. 2015;6(10):7959-69. https://doi.org/ 10.18632/oncotarget.3503.

139. Sanchez CA, Andahur El, Valenzuela R, Castellon EA, Fulla JA, Ramos CG, et al. Exosomes from bulk and stem cells from human prostate cancer have a differential microRNA content that contributes cooperatively over local and pre-metastatic niche. Oncotarget. 2016;7(4):3993-4008. https://doi.org/10.18632/oncotarget.6540.

140. Cho JA, Park H, Lim EH, Lee KW. Exosomes from breast cancer cells can convert adipose tissue-derived mesenchymal stem cells into myofibroblast-like cells. Int J Oncol. 2012;40(1):130-8. https://doi.org/ 10.3892/ijo.2011.1193.

141. Narayanan R, Huang CC, Ravindran S. Hijacking the cellular mail: exosome mediated differentiation of mesenchymal stem cells. Stem Cells Int. 2016;2016:3808674. https://doi.org/10.1155/2016/3808674.

142. Lai RC, Tan SS, Teh BJ, Sze SK, Arslan F, de Kleijn DP, et al. Proteolytic potential of the MSC exosome proteome: implications for an exosomemediated delivery of therapeutic proteasome. Int J Proteomics. 2012;2012:971907. https://doi.org/10.1155/2012/971907.

143. Chen TS, Lai RC, Lee MM, Choo AB, Lee CN, Lim SK. Mesenchymal stem cell secretes microparticles enriched in pre-microRNAs. Nucleic Acids Res. 2010;38(1):215-24. https://doi.org/10.1093/nar/gkp857.

144. Whiteside TL. Exosome and mesenchymal stem cell cross-talk in the tumor microenvironment. Semin Immunol. 2018;35:69-79. https://doi. org/10.1016/j.smim.2017.12.003

145. Di Trapani M, Bassi G, Midolo M, Gatti A, Kamga PT, Cassaro A, et al. Differential and transferable modulatory effects of mesenchymal stromal cell-derived extracellular vesicles on T, B and NK cell functions. Sci Rep. 2016:6:24120. https://doi.org/10.1038/srep24120.

146. Marote A, Teixeira FG, Mendes-Pinheiro B, Salgado AJ. MSCs-Derived exosomes: cell-secreted nanovesicles with regenerative potential. Front Pharmacol. 2016;7:231. https://doi.org/10.3389/fphar.2016.00231.

147. Dostert G, Mesure B, Menu P, Velot E. How do mesenchymal stem cells influence or are influenced by microenvironment through extracellular vesicles communication? Front Cell Dev Biol. 2017;5:6. https://doi.org/ 10.3389/fcell.2017.00006.

148. Burnstock G, Di Virgilio F. Purinergic signalling and cancer. Purinergic Signal. 2013;9(4):491-540. https://doi.org/10.1007/s11302-013-9372-5.

149. Ueda G, Shimizu C, Saito J, Tanaka Y, Inoue M, Tanizawa O. An immunohistochemical study of colon-ovarian tumor antigen and colon-specific antigen in gynecologic tumors. Gynecol Oncol. 1989;35(1):90-2. https://doi.org/10.1016/0090-8258(89)90019-x.

150. Bliss SA, Sinha G, Sandiford OA, Williams LM, Engelberth DJ, Guiro K, et al. Mesenchymal stem cell-derived exosomes stimulate cycling quiescence and early breast cancer dormancy in bone marrow. Cancer Res. 2016;76(19):5832-44. https://doi.org/10.1158/0008-5472. CAN-16-1092.

151. Bruno S, Collino F, Deregibus MC, Grange C, Tetta C, Camussi G. Microvesicles derived from human bone marrow mesenchymal stem cells inhibit tumor growth. Stem Cells Dev. 2013;22(5):758-71. https:// doi.org/10.1089/scd.2012.0304.

152. Wu S, Ju GQ, Du T, Zhu YJ, Liu GH. Microvesicles derived from human umbilical cord Wharton's jelly mesenchymal stem cells attenuate bladder tumor cell growth in vitro and in vivo. PLoS ONE. 2013;8(4):e61366. https://doi.org/10.1371/journal.pone.0061366.

153. Katakowski M, Buller B, Zheng X, Lu Y, Rogers T, Osobamiro O, et al. Exosomes from marrow stromal cells expressing miR-146b inhibit glioma growth. Cancer Lett. 2013;335(1):201-4. https://doi.org/10. 1016/j.canlet.2013.02.019

154. Di Leva G, Garofalo M, Croce CM. MicroRNAs in cancer. Annu Rev Pathol. 2014;9:287-314. https://doi.org/10.1146/annur ev-pathol-012513-104715.

155. Cai H, Yang X, Gao Y, Xu Z, Yu B, Xu T, et al. Exosomal MicroRNA-9-3p secreted from BMSCs downregulates ESM1 to suppress the development of bladder cancer. Mol Ther Nucleic Acids. 2019;18:787-800. https://doi.org/10.1016/j.omtn.2019.09.023.

156. Che Y, Shi X, Shi Y, Jiang X, Ai Q, Shi Y, et al. Exosomes derived from miR143-overexpressing MSCs inhibit cell migration and invasion in human prostate cancer by downregulating TFF3. Mol Ther Nucleic Acids. 2019;18:232-44. https://doi.org/10.1016/j.omtn.2019.08.010.

157. Sharif S, Ghahremani MH, Soleimani M. Delivery of exogenous miR-124 to glioblastoma multiform cells by Wharton's jelly mesenchymal stem cells decreases cell proliferation and migration, and confers chemosensitivity. Stem Cell Rev Rep. 2018;14(2):236-46. https://doi.org/10.1007/ s12015-017-9788-3.

158. Lou G, Song X, Yang F, Wu S, Wang J, Chen Z, et al. Exosomes derived from miR-122-modified adipose tissue-derived MSCs increase chemosensitivity of hepatocellular carcinoma. J Hematol Oncol. 2015;8:122. https://doi.org/10.1186/s13045-015-0220-7.

159. O'Brien KP, Khan S, Gilligan KE, Zafar H, Lalor P, Glynn C, et al. Employing mesenchymal stem cells to support tumor-targeted delivery of extracellular vesicle (EV)-encapsulated microRNA-379. Oncogene. 2018:37(16):2137-49. https://doi.org/10.1038/s41388-017-0116-9.

160. Smyth TJ, Redzic JS, Graner MW, Anchordoquy TJ. Examination of the specificity of tumor cell derived exosomes with tumor cells in vitro. Biochim Biophys Acta. 2014;1838(11):2954-65. https://doi.org/10.1016/j. bbamem.2014.07.026.

161. Greco KA, Franzen CA, Foreman KE, Flanigan RC, Kuo PC, Gupta GN. PLK-1 silencing in bladder cancer by siRNA delivered With exosomes. Urology. 2016;91(241):e241-247. https://doi.org/10.1016/j.urology.2016. 01.028 .

162. Mader EK, Maeyama Y, Lin Y, Butler GW, Russell HM, Galanis E, et al. Mesenchymal stem cell carriers protect oncolytic measles viruses from antibody neutralization in an orthotopic ovarian cancer therapy model. Clin Cancer Res. 2009;15(23):7246-55. https://doi.org/10.1158/10780432.CCR-09-1292.

163. Kim J, Hall RR, Lesniak MS, Ahmed AU. Stem cell-based cell carrier for targeted oncolytic virotherapy: translational opportunity and open questions. Viruses. 2015;7(12):6200-17. https://doi.org/10.3390/v7122 921.

164. Seo SH, Kim KS, Park SH, Suh YS, Kim SJ, Jeun SS, et al. The effects of mesenchymal stem cells injected via different routes on modified IL12-mediated antitumor activity. Gene Ther. 2011;18(5):488-95. https:// doi.org/10.1038/gt.2010.170. 
165. Studeny M, Marini FC, Champlin RE, Zompetta C, Fidler IJ, Andreeff M. Bone marrow-derived mesenchymal stem cells as vehicles for interferon-beta delivery into tumors. Cancer Res. 2002;62(13):3603-8.

166. Ren C, Kumar S, Chanda D, Kallman L, Chen J, Mountz JD, et al. Cancer gene therapy using mesenchymal stem cells expressing interferonbeta in a mouse prostate cancer lung metastasis model. Gene Ther. 2008;15(21):1446-53. https://doi.org/10.1038/gt.2008.101.

167. Kauer TM, Figueiredo JL, Hingtgen S, Shah K. Encapsulated therapeutic stem cells implanted in the tumor resection cavity induce cell death in gliomas. Nat Neurosci. 2011;15(2):197-204. https://doi.org/10.1038/nn. 3019.

168. Spano C, Grisendi G, Golinelli G, Rossignoli F, Prapa M, Bestagno M, et al. Soluble TRAIL armed human MSC As gene therapy for pancreatic cancer. Sci Rep. 2019;9(1):1788. https://doi.org/10.1038/ s41598-018-37433-6.

169. Menon LG, Kelly K, Yang HW, Kim SK, Black PM, Carroll RS. Human bone marrow-derived mesenchymal stromal cells expressing S-TRAIL as a cellular delivery vehicle for human glioma therapy. Stem Cells. 2009;27(9):2320-30. https://doi.org/10.1002/stem.136.

170. Kolluri KK, Laurent GJ, Janes SM. Mesenchymal stem cells as vectors for lung cancer therapy. Respiration. 2013;85(6):443-51. https://doi.org/10. $1159 / 000351284$

171. Cavarretta IT, Altanerova V, Matuskova M, Kucerova L, Culig Z, Altaner C. Adipose tissue-derived mesenchymal stem cells expressing prodrugconverting enzyme inhibit human prostate tumor growth. Mol Ther. 2010;18(1):223-31. https://doi.org/10.1038/mt.2009.237.

172. Levy O, Brennen WN, Han E, Rosen DM, Musabeyezu J, Safaee H, et al. A prodrug-doped cellular Trojan Horse for the potential treatment of prostate cancer. Biomaterials. 2016;91:140-50. https://doi.org/10.1016/j. biomaterials.2016.03.023.

173. Osugi M, Katagiri W, Yoshimi R, Inukai T, Hibi H, Ueda M. Conditioned media from mesenchymal stem cells enhanced bone regeneration in rat calvarial bone defects. Tissue Eng Part A. 2012;18(13-14):1479-89. https://doi.org/10.1089/ten.TEA.2011.0325.

174. Levy O, Zhao W, Mortensen L, Leblanc S, Tsang K, Fu M, et al. mRNAengineered mesenchymal stem cells for targeted delivery of interleukin-10 to sites of inflammation. Blood. 2013;122(14):e23-32. https://doi. org/10.1182/blood-2013-04-495119.

175. Ren C, Kumar S, Chanda D, Chen J, Mountz JD, Ponnazhagan S. Therapeutic potential of mesenchymal stem cells producing interferonalpha in a mouse melanoma lung metastasis model. Stem Cells. 2008:26(9):2332-8. https://doi.org/10.1634/stemcells.2008-0084.

176. Chen MY, Lie PC, Li ZL, Wei X. Endothelial differentiation of Wharton's jelly-derived mesenchymal stem cells in comparison with bone marrow-derived mesenchymal stem cells. Exp Hematol. 2009;37(5):629-40. https://doi.org/10.1016/j.exphem.2009.02.003.

177. Grisendi G, Bussolari R, Cafarelli L, Petak I, Rasini V, Veronesi E, et al. Adipose-derived mesenchymal stem cells as stable source of tumor necrosis factor-related apoptosis-inducing ligand delivery for cancer therapy. Cancer Res. 2010;70(9):3718-29. https://doi.org/10.1158/00085472.CAN-09-1865.

178. Lozito TP, Tuan RS. Mesenchymal stem cells inhibit both endogenous and exogenous MMPs via secreted TIMPs. J Cell Physiol. 2011;226(2):385-96. https://doi.org/10.1002/jcp.22344.

179. Clarke MR, Imhoff FM, Baird SK. Mesenchymal stem cells inhibit breast cancer cell migration and invasion through secretion of tissue inhibitor of metalloproteinase-1 and -2. Mol Carcinog. 2015;54(10):1214-9. https://doi.org/10.1002/mc.22178.

180. Amable PR, Teixeira MV, Carias RB, Granjeiro JM, Borojevic R. Protein synthesis and secretion in human mesenchymal cells derived from bone marrow, adipose tissue and Wharton's jelly. Stem Cell Res Ther. 2014;5(2):53. https://doi.org/10.1186/scrt442.

181. Hsiao ST, Asgari A, Lokmic Z, Sinclair R, Dusting GJ, Lim SY, et al. Comparative analysis of paracrine factor expression in human adult mesenchymal stem cells derived from bone marrow, adipose, and dermal tissue. Stem Cells Dev. 2012;21(12):2189-203. https://doi.org/10. 1089/scd.2011.0674.

182. Sendon-Lago J, Seoane S, Martinez-Ordonez A, Eiro N, Saa J, Vizoso FJ, et al. Corneal regeneration by conditioned medium of human uterine cervical stem cells is mediated by TIMP-1 and TIMP-2. Exp Eye Res. 2019;180:110-21. https://doi.org/10.1016/j.exer.2018.12.004
183. Wei W, Ao Q, Wang X, Cao Y, Liu Y, Zheng SG, et al. Mesenchymal stem cell-derived exosomes: a promising biological tool in nanomedicine. Front Pharmacol. 2020;11:590470. https://doi.org/10.3389/fphar.2020. 590470.

184. Yeo RW, Lai RC, Zhang B, Tan SS, Yin Y, Teh BJ, et al. Mesenchymal stem cell: an efficient mass producer of exosomes for drug delivery. Adv Drug Deliv Rev. 2013;65(3):336-41. https://doi.org/10.1016/j.addr.2012. 07.001.

185. Kalimuthu S, Gangadaran P, Rajendran RL, Zhu L, Oh JM, Lee HW, et al. A New approach for loading anticancer drugs into mesenchymal stem cell-derived exosome mimetics for cancer therapy. Front Pharmacol. 2018;9:1116. https://doi.org/10.3389/fphar.2018.01116.

186. Lou G, Chen Z, Zheng M, Liu Y. Mesenchymal stem cell-derived exosomes as a new therapeutic strategy for liver diseases. Exp Mol Med. 2017:49(6):e346. https://doi.org/10.1038/emm.2017.63.

187. Kooijmans SA, Vader P, van Dommelen SM, van Solinge WW, Schiffelers RM. Exosome mimetics: a novel class of drug delivery systems. Int J Nanomed. 2012;7:1525-41. https://doi.org/10.2147/IJN.S29661.

188. Zhuang X, Xiang X, Grizzle W, Sun D, Zhang S, Axtell RC, et al. Treatment of brain inflammatory diseases by delivering exosome encapsulated anti-inflammatory drugs from the nasal region to the brain. Mol Ther. 2011;19(10):1769-79. https://doi.org/10.1038/mt.2011.164.

189. Parfejevs V, Sagini K, Buss A, Sobolevska K, Llorente A, Riekstina U, et al. Adult stem cell-derived extracellular vesicles in cancer treatment: opportunities and challenges. Cells. 2020. https://doi.org/10.3390/cells 9051171.

190. Ban JJ, Lee M, Im W, Kim M. Low pH increases the yield of exosome isolation. Biochem Biophys Res Commun. 2015;461(1):76-9. https://doi. org/10.1016/j.bbrc.2015.03.172.

191. Chen L, Charrier A, Zhou Y, Chen R, Yu B, Agarwal K, et al. Epigenetic regulation of connective tissue growth factor by MicroRNA-214 delivery in exosomes from mouse or human hepatic stellate cells. Hepatology. 2014;59(3):1118-29. https://doi.org/10.1002/hep.26768.

192. Batrakova EV, Kim MS. Using exosomes, naturally-equipped nanocarriers, for drug delivery. J Control Release. 2015;219:396-405. https://doi. org/10.1016/j.jconrel.2015.07.030.

193. Chen TS, Arslan F, Yin Y, Tan SS, Lai RC, Choo AB, et al. Enabling a robust scalable manufacturing process for therapeutic exosomes through oncogenic immortalization of human ESC-derived MSCs. J Transl Med. 2011;9:47. https://doi.org/10.1186/1479-5876-9-47.

194. Kidd S, Spaeth E, Dembinski JL, Dietrich M, Watson K, Klopp A, et al. Direct evidence of mesenchymal stem cell tropism for tumor and wounding microenvironments using in vivo bioluminescent imaging Stem Cells. 2009;27(10):2614-23. https://doi.org/10.1002/stem.187.

195. Parolini I, Federici C, Raggi C, Lugini L, Palleschi S, De Milito A, et al. Microenvironmental $\mathrm{pH}$ is a key factor for exosome traffic in tumor cells. J Biol Chem. 2009;284(49):34211-22. https://doi.org/10.1074/jbc. M109.041152.

196. Simons M, Raposo G. Exosomes-vesicular carriers for intercellular communication. Curr Opin Cell Biol. 2009;21(4):575-81. https://doi.org/10. 1016/j.ceb.2009.03.007.

197. van den Boorn JG, Schlee M, Coch C, Hartmann G. SiRNA delivery with exosome nanoparticles. Nat Biotechnol. 2011;29(4):325-6. https://doi. org/10.1038/nbt.1830.

198. Spugnini EP, Logozzi M, Di Raimo R, Mizzoni D, Fais S. A role of tumorreleased exosomes in paracrine dissemination and metastasis. Int J Mol Sci. 2018. https://doi.org/10.3390/ijms19123968.

199. Cocce V, Farronato D, Brini AT, Masia C, Gianni AB, Piovani G, et al. Drug loaded gingival mesenchymal stromal cells (GinPa-MSCs) inhibit in vitro proliferation of oral squamous cell carcinoma. Sci Rep. 2017;7(1):9376. https://doi.org/10.1038/s41598-017-09175-4.

200. Ye Z, Zhang T, He W, Jin H, Liu C, Yang Z, et al. Methotrexate-loaded extracellular vesicles functionalized with therapeutic and targeted peptides for the treatment of glioblastoma multiforme. ACS Appl Mater Interfaces. 2018;10(15):12341-50. https://doi.org/10.1021/acsami.7b181 35.

201. Melzer C, Rehn V, Yang Y, Bahre H, von der Ohe J, Hass R. Taxol-loaded MSC-derived exosomes provide a therapeutic vehicle to target metastatic breast cancer and other carcinoma cells. Cancers (Basel). 2019. https://doi.org/10.3390/cancers11060798. 
202. Xu H, Zhao G, Zhang Y, Jiang H, Wang W, Zhao D, et al. Mesenchymal stem cell-derived exosomal microRNA-133b suppresses glioma progression via Wnt/beta-catenin signaling pathway by targeting EZH2. Stem Cell Res Ther. 2019;10(1):381. https://doi.org/10.1186/ s13287-019-1446-Z.

203. Yuan L, Liu Y, Qu Y, Liu L, Li H. Exosomes derived from MicroRNA-148b-3p-overexpressing human umbilical cord mesenchymal stem cells restrain breast cancer progression. Front Oncol. 2019;9:1076. https://doi.org/10.3389/fonc.2019.01076.

204. Jiang S, Mo C, Guo S, Zhuang J, Huang B, Mao X. Human bone marrow mesenchymal stem cells-derived microRNA-205-containing exosomes impede the progression of prostate cancer through suppression of
RHPN2. J Exp Clin Cancer Res. 2019;38(1):495. https://doi.org/10.1186/ s13046-019-1488-1.

205. Shang S, Wang J, Chen S, Tian R, Zeng H, Wang L, et al. Exosomal miRNA-1231 derived from bone marrow mesenchymal stem cells inhibits the activity of pancreatic cancer. Cancer Med. 2019;8(18):772840. https://doi.org/10.1002/cam4.2633.

\section{Publisher's Note}

Springer Nature remains neutral with regard to jurisdictional claims in published maps and institutional affiliations.
Ready to submit your research? Choose BMC and benefit from:

- fast, convenient online submission

- thorough peer review by experienced researchers in your field

- rapid publication on acceptance

- support for research data, including large and complex data types

- gold Open Access which fosters wider collaboration and increased citations

- maximum visibility for your research: over $100 \mathrm{M}$ website views per year

At BMC, research is always in progress.

Learn more biomedcentral.com/submissions 